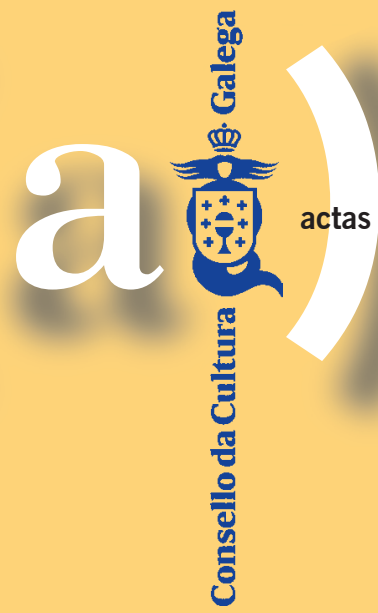

XULIO RÍOS

COORDINADOR

\title{
Vocacións e ideais de Plácido Castro
}




Vocacións e ideais de Plácido Castro 


\section{Edita}

(C) CONSELLO DA CULTURA GALEGA, 2020

Pazo de Raxoi $\cdot 2^{0}$ andar $\cdot$ Praza do Obradoiro

$15705 \cdot$ Santiago de Compostela

T $981957202 \cdot$ F 981957205

corre0@consellodacultura.gal

www.consellodacultura.gal

\section{Imaxe da cuberta}

Foto cedida pola familia de Plácido Castro

\section{Maquetación}

Lugami Artes Gráficas

DOI: 10.17075/vipc.2020 


\section{XULIO RÍOS}

COORDINADOR

\section{Vocacións e ideais de Plácido Castro}

面 
Presentación 


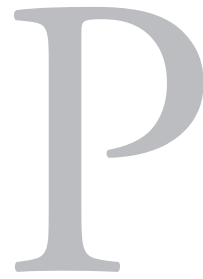

lácido Castro (Corcubión 1902-Cambados 1967) non podía faltar no inventario de persoeiros que en Galicia e desde o galeguismo estiveron comprometidos coa defensa do universalismo, cunha Galicia aberta ao mundo.

Plácido foi unha rara avis, unha figura moi singular no cosmos galeguista do pasado século e aínda hoxe é unha personalidade por descubrir en moitas das súas facetas. En realidade, fíxose galeguista estudando no Reino Unido (en Scarborough e Glasgow), onde se formou dende moi novo con parte da realeza británica. De familia acomodada e liberal, foi alí onde realmente chegou a comprender que a identidade, no plano individual e colectivo, debe partir do propio, do seu recoñecemento, dignificación e exaltación. Dende o profundo coñecemento da maneira de ser británica (nada de flegmáticos, dicía), foi quen de comprender que é na diferenza onde radica a forza do ser, pero sen que iso derive en ningunha forma de confrontación. Para el, que consideraba o nacionalismo un credo moderno, o galeguismo era unha forma de estar no mundo, un mecanismo de unión cos outros baseado no respecto.

Plácido Castro é, así, unha figura a quen ese inexorable paso do tempo lle permite gañar proxección, solvencia e lembranza. Plácido contaba cunha sólida formación, como moitos dos seus coetáneos galeguistas que conformaron unha xeración irrepetible. A diferenza doutros, claramente filoxermanos, o imaxinario do noso Plácido amosaba un perfil inevitablemente anglosaxón. Do Reino Unido, Irlanda e o mundo céltico que tanto admiraba chegou a ser un profundo coñecedor e a el acudía para escribir fermosas crónicas e relatos pero tamén para analizar a súa actualidade política, económica, cultural ou social. Nesas orixes e 
converxencias identificaría un dos sinais de identidade da nosa forma ser como é a saudade, que interpretaba nun sentido abertamente contrario ao tópico.

A súa profunda devoción pola poesía e o dilatado coñecemento da lingua inglesa imprimiron nel o interese pola tradución. Así, Plácido realizou excelentes traducións poéticas tamén teatro que hoxe se recoñecen como pioneiras dese labor en Galicia.

En Plácido Castro non hai contradición entre o dominio do inglés e doutras linguas e o amor á propia, entre ser cidadán do mundo e asumir unha fonda identidade de seu, entre ser nacionalista e alentar a unión universal dos pobos, entre ser moderno e apostar polo progreso e dignificar as vigas esenciais do noso ser, mesmo entre contar cunha posición ben acomodada e avogar pola dignidade e a xustiza social. Todos estes son tópicos habituais nos que a nosa sociedade malgasta inxentes enerxías autodestrutivas e para os que a vida, obra e pensamento do noso autor achegan solucións tan firmes como conciliadoras.

Eternamente preocupado pola salvagarda da identidade de Galicia, polo reencontro de Galicia consigo mesma en todos os dominios (da lingua á paisaxe, pasando polo turismo e calquera manifestación cultural), todo debía ser dignificado e enxalzado para construír un futuro en que debiamos exercer de nós. El, que tantos anos vivira no Reino Unido, antes e despois da Guerra Civil española, participando nas emisións da BBC en lingua galega, castelá e inglesa, quen chegou a colaborar durante varios anos no Jornal de Notícias de Porto, comprendía mellor ca ninguén o significado desa proxección universalista que el unía á admiración do progreso.

Plácido Castro encarna valores e actitudes de gran significación no noso presente: o altruísmo, o pacifismo, o humanismo; en fin, a devoción por unha Galicia de seu, xenerosa, con autoestima, reivindicada e reivindicable, aberta ao mundo. O rigor, o compromiso, a modestia e a elegancia que sempre observou en vida deben ser acicates para que esteamos á altura de lle ofrecer o recoñecemento que tanto merece. Por fortuna, eses tempos van chegando. 
No universo do galeguismo e o nacionalismo, poucas figuras como a de Plácido Castro ofrecen unha traxectoria e un pensamento tan orixinal. Plácido entendía así o galeguismo: unha admiración profunda polas culturas alleas coa esperanza da normalización da propia, nunca menos considerada a sabendas de que só así Galicia podería estar en condicións de dialogar co resto do mundo.

Con independencia da época e das súas vicisitudes anímicas, hai sempre unha foto fixa, a do Plácido do diálogo, da tolerancia, do librepensamento, da curiosidade, da fe e conviccións democráticas profundas, do gusto polo traballo ben feito e con rigor, daquel individuo culto e amador da cultura que preferiu falar con voz baixa ou simplemente calar antes que dobrar a cerviz ante a tiranía da ignorancia e da mediocridade.

Cambados representou moito na vida de Plácido Castro. Na vila do Salnés pasou parte dos veráns na súa mocidade antes da guerra. E despois dela, á volta do exilio londiniense, nela atoparía acubillo quen a partir de entón sería coñecido entre os seus conveciños como «O inglés» e se sumaría, cos límites da época, a iniciativas culturais e sociais que hoxe gozan aínda de excelente saúde.

\section{Xulio Ríos}

Coordinador da xornada e da Comisión de Acción Exterior (CCG) 


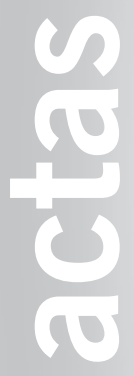

Índice 


\section{PRESENTACIÓN}

Xulio Ríos

13 Tradución e resistencia en Plácido Castro: construír Galicia nas Rubáiyát de Omar Kháyyám

Laura Linares

35 Plácido R. Castro, tradutor e anglista da galeguidade nas Rubáiyát María Jesús Lorenzo Modia

53 Plácido Castro e o xornalismo

César Lorenzo Gil

61 Plácido Castro e a prensa da súa época Luís Álvarez Pousa

79 Plácido Castro e o universalismo

Rubén C. Lois González

95 Plácido Castro e o universalismo galeguista

Xulio Ríos 


\section{TRADUCIÓN E RESISTENCIA EN PLÁCIDO CASTRO: CONSTRUÍR GALICIA NAS RUBÁIYÁT DE OMAR KHÁYYÁM}

\section{Laura Linares}

University College Cork

DOI: 10.17075/vipc.2020.001 

Plácido Castro, nado en Corcubión no ano 1902 e formado en terras escocesas, foi un salientable intelectual galego que exerceu de mediador entre as culturas europeas anglófonas e Galicia, non só a través das súas versións de obras irlandesas e británicas, senón tamén coas súas crónicas de viaxe a Irlanda para El Pueblo Gallego $(1928 ; 2013)$ ou a súa participación nos programas galegos da BBC durante o seu exilio en Inglaterra nos anos 40 e principios dos 50 (1994), entre outras moitas iniciativas e actividades de promoción da cultura galega. A súa traxectoria intelectual posiciónao como galeguista a prol da dignificación e fomento da lingua e a cultura galegas, cun claro compromiso pola re-construción dunha identidade cultural e nacional galega, mentres que a súa conexión coa cultura e sociedade británicas e o seu posicionamento en defensa do liberalismo e a democracia sitúano nun papel moi claro de resistencia contra a ditadura franquista e a fagocitación da identidade galega por parte dun Estado español considerado centrípeto e opresivo. Esta posición ideolóxica reflíctese de xeito consistente na súa faceta tradutora a través das súas escollas textuais e lingüísticas, que supoñen un claro exemplo da importancia do estudo da ideoloxía e o activismo político e cultural nas traducións, particularmente en contextos minorizados coma o galego. As seccións que seguen proporcionan unha breve introdución ao papel de Castro como tradutor e intelectual galego e analizan as súas estratexias tradutoras na que foi probablemente a súa obra máis importante, a versión galega das Rubáiyát de Omar Kháyyám, para demostrar como a tradución non é nunca unha actividade neutra de simple transferencia lingüística, senón que pode utilizarse como medio de resistencia e de construción dunha cultura. 


\section{PLÁCIDO CASTRO E A TRADUCIÓN COMO RE-CONSTRUCIÓN DA IDENTIDADE GALEGA: O PERÍODO NÓS}

Tras a súa infancia en Escocia e o seu paso pola universidade no mesmo país, Castro regresou a Galicia en 1930 e integrouse activamente na vida intelectual e política do momento. Para el, coma para moitos dos intelectuais galegos da altura, a lingua tiña un papel esencial na re-construción da identidade nacional e cultural galega e na diferenciación da cultura galega da castelá. En 1916, Antón Villar Ponte publicou Nacionalismo gallego. Nuestra «afirmación» regional, onde promovía a defensa da lingua galega e sentaba as bases do que despois se convertería nas Irmandades da Fala, nas que Castro participaría activamente na Coruña. Como ben afirma xa en 1928, «o feito de ser unha creación do noso pobo é unha razón que abonda para que o galego sexa para nós a lingua máis importante do mundo» (Castro 1928b). A normalización da lingua galega era considerada, polo tanto, como un elemento esencial para o desenvolvemento dunha comunidade nacional, o cal resultou no deseño dun programa estratéxico para a súa promoción e defensa no que se incluían non só as propias Irmandades, senón tamén as que se converterían nas dúas principais revistas culturais da altura: A Nosa Terra e Nós. Precisamente esta última, que acabou sendo a revista de vangarda literaria e filosófica da época, foi unha publicación clave de textos vidos doutras linguas e culturas. Malia a tradución —especialmente de textos clásicos e bíblicos- estar presente na Galicia do século XX xa desde os seus inicios (Noia 1995: 48), sería durante o período Nós cando as traducións comezarían a ter un papel moito máis predominante na sociedade galega e na formación da identidade propia. Como xa mostran estudos previos (Millán Varela 1998; McKevitt 2003; Vázquez Fernández 2013), os membros do grupo Nós, incluído Plácido Castro, sentían unha responsabilidade moral cara á re-construción dunha cultura nacional que tomou forma a través de dous piares fundamentais: o retorno ás raíces tradicionais, por unha banda, e a integración coa innovación vida doutras culturas e co universalismo pola outra (Millán Varela 1998). Neste sentido, un 
dos seus obxectivos principais era acceder ás culturas de Europa directamente, sen interferencias de Castela, tal e como se indica nun dos principios da revista: "A Galiza incorporada, sen intermediarios importunos e costosos á comunidade da cultura das nazóns do Norte d'Europa, á que pertenceu nos tempos groriosos da civilización enxebre» (Nós 1922: 17). A tradución, polo tanto, convértese nun instrumento fundamental para acceder á innovación doutros sistemas literarios mentres se continuaba a promover e normalizar a lingua galega. Como ben di Álvarez Lugrís, «neste momento tradúcese para recupera-la identidade; calquera outra consideración carece de importancia. Tradúcese non para crear literatura senón para crear conciencia» (2005).

Tanto A Nosa Terra coma Nós publicaron traducións de xéneros variados, mais centradas especialmente en autores europeos contemporáneos (vid. Real Pérez 2001). Entre as traducións que se publicaron nas revistas vese unha grande influencia de textos irlandeses e da consideración de Irlanda como modelo para os nacionalistas galegos. Non só era Irlanda membro da comunidade celta, senón que a creación do Estado Libre en 1921 e o rexurdimento literario que se vivía no país na altura eran unha gran fonte de inspiración para os intelectuais galegos (Toro Santos 1994: 45). Entre as obras vertidas ao galego está a tradución realizada por Castro e os irmáns Villar Ponte en 1935 da obra The Land of Heart's Desire, considerada «a última, e se cadra a máis relevante, tradución realizada no período Nós» (Vázquez Fernández 2013: 61). O país da saudade, como se titulou en galego, e a versión revisada da versión de Cathleen Ni Houlihan (en galego, Catuxa ni Houlihan) de Villar Ponte, que xa publicara Nós en 1921, publicáronse en 1935 baixo o título Dous folk-dramas de W. B. Yeats e constitúen a primeira tradución publicada en formato libro neste período (Noia 1995: 50). No prefacio pódese ver non só un resumo das razóns políticas para a tradución dos textos, senón tamén unha breve reflexión sobre o proceso de tradución que desenvolvería Plácido Castro con máis profundidade en futuros traballos. Nos Dous folk-dramas, os tradutores falan das ideas de enxebrismo, celticismo e saudade, e describen a tradución como un proceso de transplante de flores (ideas) dunha cultura para outra. 
C'o pensamento posto nos coros enxebres pillamos d'un horto da Illa Verde co'a fouce druída do luar estas flores que enfeita o orballo celta da saudade, común a todol-os pobos da mesma raza, para ofrecerllas vizosas logo d'as ter transplantadas con labrego agarimo á nosa doce língoa atlántica feita salaios d'amor nos Cancioneiros. (Yeats 1935; negriñas da autora)

Esta metáfora da tradución como transplante podería responder á idea de «integrar [o texto] na cultura galega, onde contribuirá á formación dunha identidade nacional galega» (Vázquez Fernández 2013: 95), mais está tamén relacionada coa idea de Castro da tradución como re-produción (Castro 1965: 166), que desenvolve en máis profundidade no prefacio da súa versión das Rubáiyát de 1965, onde argumenta que a versión creada por Edward FitzGerald é «a obra dun poeta inspirada pola obra dun poeta — non unha copia senón unha re-produción, non unha tradución senón a re-entrega dunha impresión poética» (Castro 1965: 166).

Esta idea da tradución como reprodución lémbranos a idea de «re-writing», promovida polo intelectual Lefevere (1992): as traducións non suceden nun baleiro e, polo tanto «reflicten unha certa ideoloxía e poética e, como tal, manipulan a literatura para que esta funcione dentro dunha sociedade determinada» (Lefevere 1992: xii, tradución da autora). Xa que o que se reproduce é a «impresión» do poema, a tradución consiste nunha nova lectura e escrita do texto, e polo tanto é susceptible á manipulación do tradutor. Neste caso, a posición activamente comprometida coa re-construción e o desenvolvemento da identidade galega de Plácido Castro como intelectual e parte activa das Irmandades da Fala, do Partido Galeguista e do grupo Nós, así como o seu propio posicionamento e reflexións teóricas e persoais sobre o proceso tradutor, suxiren que as súas versións poden terse utilizado como medio de promoción e recuperación da lingua galega e como resistencia contra a forza opresora da ditadura franquista e o poder centralizador representado por Castela. 


\section{A GUERRA CIVIL E A DITADURA FRANQUISTA EN GALICIA: A DISRUPCIÓN DO DISCURSO LITERARIO GALEGO}

O golpe militar de Francisco Franco contra o Goberno da República o 18 de xullo de 1936 e a subsecuente Guerra Civil supuxo, en Galicia, unha fera represión e, no terreo intelectual, a completa disrupción do discurso literario (Vilavedra 1999: 209). Durante eses anos, a literatura e a cultura galegas experimentaron un profundo illamento e falta de materiais tanto orixinais - pois moitos dos intelectuais da altura ben emigraran, ben foran executados — coma importados, pois estes non entraban na cultura debido aos obstáculos interpostos polas clases gobernantes á entrada de novas tendencias de fóra. A lingua galega, malia non quedar completamente prohibida, foi obxecto de constante persecución, cunha clara imposición do castelán (Fernández Rodríguez 2012: 172) ${ }^{1}$.

As publicacións e traducións en galego eran limitadas e aparecían fundamentalmente nas poucas revistas periódicas creadas tanto en Galicia coma no exilio. Como resume Áurea Fernández Rodríguez, «los contados textos que se han podido localizar en publicaciones periódicas de Galicia durante la posguerra han sido publicados en revistas literarias locales gracias al empeño de unos pocos intelectuales entusiastas» (2012: 174). De feito, e probablemente debido a esta falta de materiais e recursos, hai un número ben limitado de estudos sobre a tradución da época, sendo as contribucións máis relevantes as de Dasilva (2013), Fernández Rodríguez (2012), Garrido Vilariño e Luna Alonso (1999) ou Luna Alonso (2012).

Coma en moitas outras áreas da evolución da identidade, o discurso e a literatura galegas, as comunidades exiliadas en América Latina foron cruciais para

\footnotetext{
${ }^{1}$ A vida de Plácido Castro é un exemplo paradigmático da disrupción do discurso galeguista. Mentres que en anos anteriores fora moi politicamente activo,como xa se comentou, co comezo da Guerra Civil retirouse da esfera pública e centrouse fundamentalmente no seu labor como tradutor de poesía. En 1949 trasladouse ao Reino Unido para escapar do ambiente opresivo e traballou como locutor de radio para os programas español e galego da BBC. Non regresaría a Galicia ata o ano 1956.
} 
a aparición das poucas traducións publicadas na época. A contribución máis importante deste tempo, na que se reitera o papel de Castro como mediador entre culturas, é a publicación de Poesía inglesa e francesa vertida ao galego (1949), pola que Lois Tobío, Florencio Delgado Gurriarán e Plácido Castro obtiveran o premio, como tradutores, da Federación de Sociedades Galegas de Bos Aires en 1946. A tradución adquire aquí un valor verdadeiramente simbólico como punto de contacto con outras culturas e tradicións literarias, que os galegos no exilio promocionaron a través das editoriais creadas e, sobre todo, a través das numerosas revistas culturais que apareceron nos primeiros anos despois da guerra. Nelas, a tradución de autores europeos como Rilke, Rudyard Kipling e outros impulsou a renovación cultural e literaria daquelas comunidades (Fernández Rodríguez 2012).

Durante os anos 50 e 60, o sistema literario galego viu un desenvolvemento moito máis rápido ca na década previa, parcialmente grazas á creación da editorial Galaxia por parte de Francisco Fernández del Riego e Xaime Illa Couto. Un dos primeiros proxectos de Galaxia foi a revista Grial, herdeira das ideas culturais e do espírito universalista de Nós (Vilavedra 1999: 212). A revista comezou o seu percorrido en 1950 e, malia ser suspendida entre 1951 e 1963 debido ás políticas sobre publicacións periódicas da altura, volvería ser publicada, desta vez xa sen interrupcións, desde 1963 ata o presente.

Do mesmo xeito que Nós no período previo, Grial serviu como medio de redefinición da identidade galega e como xeito de defender e promover a lingua e a cultura galegas. A responsabilidade moral da re-construción dunha identidade cultural seguía presente no grupo Galaxia e, malia as diferenzas en cuestións políticas, o programa de Grial compartía certas semellanzas co do grupo Nós. O regreso ás raíces tradicionais e a integración da cultura galega con outras a través dunha visión universalista seguiron a ser ideas chave, como tamén o foi a insistencia no uso da lingua galega como medio de expresión, vista como estratexia clara de resistencia ante un poder dominante que oprimía a lingua e 
a cultura galegas (Fernández Rodríguez 2012: 183). O uso da lingua tanto en creacións orixinais coma en traducións, polo tanto, foi unha manifestación da loita contra a intolerancia do réxime e unha reafirmación da identidade galega.

As principais linguas fonte de tradución en Grial nos primeiros anos da vida da revista foron o francés, o inglés e o alemán, malia que linguas máis distantes coma o xaponés tamén están presentes, a miúdo vertidas ao galego a través dunha versión ponte nunha lingua europea (Luna 2012: 188). Malia Camiño Noia argumentar que todas as traducións se realizaban «por iniciativa individual, segundo os intereses e a competencia das linguas do propio tradutor ou promovidas por algún grupo de galeguistas, pero non son o froito dunha planificación editorial nin a longo nin a curto prazo» (1995: 53), as cartas de Fernández del Riego en resposta aos envíos para publicación na revista non deixan dúbida de que o proceso de selección, malia estar limitado polos escasos recursos, era estrito e centrado especificamente na revitalización e a dignificación da lingua e a literatura galegas. Como afirma categoricamente Fernández del Riego nunha carta ao escritor Ben-Cho-Shey:

Mira: no esforzo que fixemos pra pór en marcha a Galaxia e no que agora facemos pra sostela [...] móvenos unha única arela: promover e prestixiar a cultura galega. Fíxate ben, promover e prestixiar a nosa cultura. [...] Ora, pra promover e pra prestixiar a nosa cultura necesitamos operar con dúas bases: medios materiales e criterio seleitivo. (Fernández del Riego n.d.; subliñados da autora)

Ao implementar este proceso de selección, os editores de Grial buscaban garantir que os principais obxectivos da publicación — promover e prestixiar a cultura galega - quedaban debidamente cumpridos, e utilizar a revista como ferramenta para a construción e o desenvolvemento da identidade cultural galega e a resistencia contra a situación de dominación cultural imposta polo réxime franquista en Galicia. 


\section{GRIAL E AS RUBÁIYÁT DE OMAR KHÁYYÁM: A TRADUCIÓN COMO MEDIACIÓN E RESISTENCIA}

Da creación desa conciencia nacional galega e da promoción e prestixio da cultura temos exemplos claros nas estratexias tradutoras de Castro nas Rubáiyát de Omar Kháyyám, publicadas en Grial no ano 1965. Castro toma a famosa versión inglesa de Edward FitzGerald, publicada en primeira edición en 1859, e crea unha versión galega moi aproximada formalmente á británica. Falamos de 75 estrofas separadas en dúas seccións: as primeiras 48 e as últimas 8 están organizadas baixo o nome xeral de The Rubáiyát of Omar Khayyám, As Rubáiyát de Omar Khayyám en galego, mentres que as estrofas LIX-LXVI son parte dunha subdivisión nomeada «Kuza-Nama». Castro mantense próximo a esta división, en liña co que indica na súa introdución ao texto.

Tentóuse nista versión galega conservar no esencial e posibre a semellanza coa forma e rima das cuartetas inglesas. Inda que, naturalmente, dádalas caraiterísticas das dúas falas, teña que ser o verso galego máis longo que o inglés. (Castro 1965:168)

A versión galega, efectivamente, tende a ser máis longa ca a inglesa, algo que Castro atribúe ás características específicas da lingua galega. Porén, a rima AABA procedente da versión inglesa respéctase en todas as estrofas. Esta rima fora preservada por FitzGerald do orixinal persa e constituíu unha revolución na poesía inglesa grazas á introdución dunha estrutura completamente nova que, malia ter ecos en formas inglesas coma o limerick (Gray 2001: 782), non se utilizara ata a altura como tal. Malia Castro non mencionar o patrón rítmico no seu prefacio ou nas súas notas, a súa decisión de mantelo en lugar de «traducilo» a un patrón máis familiar podería formar parte do seu desexo de introducir innovacións formais na poesía galega.

Outras dúas formas moi claras da proximidade entre as versións galega e inglesa no nivel formal son o tratamento das maiúsculas e a tipografía dos nomes persas. Como explica Castro no prefacio: 
No que respeita á ortografía de nomes e verbas persas que se emprega niste volume,

[...] me limito a reproducir o que foi feito hai anos polo autor da versión inglesa. [...] Consérvase, ademáis, o costume de FitzGerald de escreber os sustantivos con maiúscula, así como certas outras peculiaridades ortográficas da versión inglesa. (Castro 1965: 169)

Castro segue o uso idiosincrático de FitzGerald das maiúsculas para os substantivos do poema mesmo cando en galego se dá un cambio de categoría gramatical, adaptando de xeito consistente a grafía á presenza de substantivos na tradución galega:

And Lo! The Hunter of the East has caught

The Sultan's Turret in a Noose of Light (I)

[E] o Cazador do Leste, no seu Lazo de Luz

Á Torre do Sultán ten feito Prisioneira (I)

No que respecta aos nomes persas, na versión galega non só se manteñen os nomes dos personaxes do poema, senón que a maior parte da imaxinaría relacionada cos versos queda preservada con explicacións extensas nas notas ao final do poema. Un bo exemplo desta estratexia aparece xa na primeira estrofa:

Awake! For Morning in the Bowl of Night

Has flung the Stone that puts the Stars to Flight:

And Lo! The Hunter of the East has caught

The Sultan's Turret in a Noose of Light. (I)

Despertai! Que a Mañán xa lanzou a súa Pedra

Na cunca desta Noite, i escorrenta as Estrelas:

E o Cazador do Leste, no seu Lazo de Luz

Á Torre do Sultán ten feito Prisioneira. (I) 
A estrofa está conectada coa primeira nota ao final da tradución, na que Castro aclara:

A aición de deitar unha pedriña na copa era, na Persia, o sinal pra a dispersión da xuntanza. Entón os reunidos montaban a cabalo e partían a través do deserto. A súa partida, di FitzGerald, era o aviso pra que se xuntaran os Bebedores. O profesor Arberry danos a seguinte versión literal do orixinal persa: «O Sol atirou o lazo do amañecer sobre do teito; o emperador do día lanzou a pedra na copa». (Castro 1965: 184)

A través do achegamento á versión de FitzGerald co seu uso similar das maiúsculas, a conservación das grafías dos nomes persas e o uso de notas aclaratorias sobre elementos culturais persas, Castro acerca o lectorado galego á cultura de orixe (mediada, por suposto, pola tradución de FitzGerald), salientando os elementos diferenciadores e destacando o papel activo que o lector/a galego/a debe tomar na lectura do poema (consultando as notas, considerando as grafías) para unha comprensión profunda do texto.

Porén, a través dunha análise detallada da súa versión queda claro que Castro non segue esta estratexia de xeito regular e que, de feito, é nas partes que se presentan como máis culturalmente neutras ou que non especifican aspectos concretos da cultura persa nas que o tradutor achega de novo o texto á familiaridade do contexto galego, como nos seguintes exemplos:

But still the Vine her ancient Ruby yields And still a Garden by the Water blows
Mais segue dando a Vide o seu Rubí de sempre

E o Xardín da Ribeira segue cheo de Frores (V)
Beside me singing in the WildernessAnd Wilderness is paradise enow
E Ti, á miña beira, a cantares no Ermo-

E abondaría o Ermo pra ser un Paraíso.

(XI) 
Like Snow upon the Desert's dusty Face Lighting a little Hour or two-is gone

They say the Lion and the Lizard keep The Courts where Jamshyd gloried and drank deep
Cal Neve que se pousa sobre do Pó do Ermo Por unha curta Hora ou dúas- logo vaise. (XIV)

Din que León e Lagarto no Pazo están vivindo

Onde Yamshyd, no orgulo, bebéu fondo do Viño

(XVII)

Pó convertido en Pó e baixo Pó xacente, Sen Viño, sen Cantiga, sen Cantor -e sen Termo!

(XXIII)

Todos estes exemplos transportan a lectura a un territorio familiar, no que o exótico Garden by the Water se transforma no concepto moito máis próximo de «Ribeira», e os poeirentos Desert e Wilderness afástanse da idea do «deserto» e convértense nuns «Ermos» moito máis achegados á realidade galega. Máis destacable aínda é a tradución de Courts como «Pazo»: aquí, a imaxe da construción caracteristicamente galega contrasta claramente coa imaxe exótica do león e o lagarto e insta o lector a acceder a un espazo liminar no que o foráneo se entretece co familiar. Chegados a este punto, é tamén esencial destacar que estes exemplos non só achegan o texto ao lectorado galego, senón que o fan utilizando elementos que só están presentes ou son típicos da cultura galega, reducindo así a distancia coa Persia do século XII, á vez que se expande a fenda entre Galicia e algúns aspectos culturais casteláns. A intencionalidade desta estratexia revélase máis polo miúdo cando comparamos a versión final de Castro con dous borradores inéditos da súa tradución: 


\section{Borrador 1}

Nos Patios onde Yámshyd, no Esplendor, bebe Viño
Borrador 2

Din que león e Lagarto no

Pazo están vivindo

\section{Versión final}

Din que León e Lagarto no

Pazo están vivindo

(XVII)

O que se traducira nun primeiro momento de xeito máis literal, é dicir, Courts, como «Patios», que coincide ademais coa palabra patios en castelán, transfórmase a partir do segundo borrador no termo «Pazo», cunhas connotacións culturais moito máis claras. Do mesmo xeito, no último exemplo, a elección do termo "Cantiga» como tradución de Song en inglés segue a mesma estratexia: malia "canción» e "cantiga» seren sinónimos en galego, este último ten unhas connotacións culturais e emocionais moito máis fortes, pois o seu uso está habitualmente restrinxido ou ben ás pezas de música tradicional e popular, ou ben ás composicións líricas medievais. Para máis, é o único dos dous termos que non ten un equivalente exacto en castelán, o cal destaca, unha vez máis, a vontade de diferenciación tanto cultural coma lingüística da tradución de Castro. A elección deste termo vai, ademais, en liña co recordatorio do tradutor, no seu prefacio, de que as Rubáiyát de Omar Kháyyám coincidiron no tempo cos cancioneiros medievais galegos (Castro 1965: 167).

Polo tanto, malia si destacar os aspectos máis característicos da cultura persa, Castro non prioriza o achegamento ao orixinal en todas as ocasións, senón que utiliza estratexias que non só acercan o texto ao contexto galego senón que ademais o fan utilizando vocabulario especificamente galego e termos relacionados coa cultura galega, aumentando así tamén a distancia entre esta e a cultura castelá. Isto mostra unha clara estratexia de diferenciación lingüística e resistencia cultural contra o que se consideraba o poder opresivo do Estado español en Galicia. 


\section{CAMBIOS DE REXISTRO: O RETORNO ÁS RAÍCES A TRAVÉS DA LINGUA}

Unha das diferenzas máis destacables entre a versión das Rubáiyát de FitzGerald e a galega é o cambio xeral de rexistro lingüístico. Mentres que a versión inglesa mantén a formalidade e inclúe unha gran cantidade de formalismos, a tradución ao galego utiliza un vocabulario moito máis moderno e un rexistro máis coloquial. Como comenta Venuti, as «estratexias discursivas revelan a historicidade dunha tradución na propia textura da súa lingua. A invención por parte do tradutor dun vocabulario e unha sintaxe para o texto fonte pode basearse en dialectos ou estilos prevalentes no período en que se produciu a tradución» (2013: 106, tradución da autora). As Rubáiyát de FitzGerald favorecen un estilo arcaizante, típico da época vitoriana, que na súa tradución se caracteriza polo uso das formas arcaicas thee, thou e thy, amais de expresións como And lo!, enow, e de verbos arcaicos como know'st, entre outros. No século XIX, estas formas desapareceran xa da lingua inglesa estándar e só se utilizaban en poesía, o cal contribúe á exotización do texto para os lectores vitorianos. En galego, porén, estas formas desaparecen ou son substituídas por formas moito máis modernas e coloquiais. As formas thee, thy e thou, por exemplo, son substituídas polo uso informal de «ti», «teu», «-che» ou «-te»:

Some little talk awhile

Of ME and THEE

Make Game of that which

Makes as much of Thee
Semellóu que falaban

Un pouquiño de TI

(XXXII)

Do que nos fai mofa, Imos tamén mofarnos (XLV) 
Then fancy while Thou art

Thou art but what

Thou shalt be -Nothing-

Thou shalt not be less

Draws up to Thee -take that,

And do not shrink
Namentras inda eisistes

Maxina que eres sóio

O que vas ser máis tarde

-Nada- non has ser menos

(XLVII)

Seu Trago máis escuro

¡Ti bebe sen tremeres!

(XLVIII)

Para máis, as estruturas arcaicas que aparecen na versión inglesa elimínanse completamente do texto en galego:

And Lo! The Hunter of

The East has caught

And Wilderness is

Paradise enow

Hither and tither moves

And mates, and slays
E o Cazador do Leste,

No seu Lazo de Luz

(I)

E abondaría o Ermo

Pra ser un Paraíso

(XI)

Móveas eiquí e aló,

Dalles mate e as mata

(XLIX)

¿De onde véu, e pra onde voóu?

¿E quén o sabe?

(LXXII) 
Nalgúns casos, ademais, estas expresións arcaicas substitúense por expresións de rexistro moito máis coloquial, como no caso de pish, que se transforma no informal «QQué parvada!» (LXIV) ou hither and tither (XLIX), que lle dá reminiscencia á lingua de Shakespeare no inglés, queda transformado no máis coloquial «eiquí e aló», que evoca unha lingua significativamente máis oral. Esta tendencia ao uso dun rexistro máis coloquial na versión galega das Rubáiyát mantense ao longo de todo o poema, mesmo en casos nos que o inglés non segue unha tendencia tan arcaizante:

But still the Vine her

Ancient Ruby yields

Let Rustum lay about him

As he will

Or Hátim Tai

Cry Supper

Listen again. One Evening

At the Close

It murmur'd -"Gently, Brother,

Gently, pray!”
Mais segue dando a

Vide o seu Rubí de sempre

(V)

Que loite Rustúm

Como lle pete

(IX)

Deixa que Hátim Tai

Pida a berros a Céa

(IX)

Escoitaime -Á Noitiña,

Cando findando ía

(LIX)

«Docemente, con xeito,

Meu Irmán!» -marmuraba

(XXXVI) 
Particularmente salientable entre estes exemplos é a tradución de as he will por «como lle pete», que implica un cambio de rexistro certamente radical do orixinal e, de novo, inclúe unha expresión tipicamente galega. A intencionalidade desta elección faise aínda máis clara cando se analizan os dous borradores previos da tradución de Castro, nos que a evolución se ve claramente:

\section{Borrador 1 \\ Que loite Rustúm}

Como desexe

\section{Borrador 2}

Que loite Rustúm

Como lle pete
Versión final

Que loite Rustúm

Como lle pete

(IX)

Esta estratexia de cambio de rexistro segue a liña das prioridades diferenciadoras de Castro e dos intelectuais tanto do grupo Nós como de Galaxia, baseadas non só na universalidade e o contacto directo con outras culturas, senón tamén no retorno ás raíces galegas: entre elas, a lingua oral, como representante da tradición e da cultura popular, é un elemento fundamental na dignificación da cultura e da identidade nacional galega.

Pódense atopar máis exemplos da intencionalidade diferenciadora de Castro na súa tradución no uso exhaustivo e consciente de estruturas sintácticas tipicamente galegas. Un exemplo disto é o uso da estrutura verbal «a + infinitivo», que en galego se pode utilizar como substituto do xerundio, co mesmo significado. Ambas estruturas son válidas e, polo tanto, queda clara a intencionalidade cando Castro utiliza a que é tipicamente galega mesmo en casos nos que pode causar confusión, como no exemplo que segue:

"Laughing," she says,

"Into the World I blow"
Cheguei ó Mundo a rirme,

Meus Pétalos abrín

(XIII)

Aquí, «a rirme» [sic] pode significar tanto «rindo» como "para rir, co propósito de rir» e, polo tanto, o uso da preposición co infinitivo prioriza claramente 
a diferenciación lingüística por riba da aclaración do sentido do verso. Outro exemplo desta preferencia por construcións exclusivamente galegas é o seu uso do antepretérito, mesmo en casos nos que implica un leve cambio de significado, como no seguinte exemplo:

And those who flung it to the

Winds like Rain
Nin os que como Choiva nos

Ventos a espallaran

(XV)

Un exemplo aínda máis claro desta estratexia aparece na estrofa LXIX, na que the idols I have loved so long se transforma en «os ídolos que amara», cambiando polo tanto a referencia pasada. Nos borradores de Castro vese a vacilación entre as dúas opcións:

$\begin{array}{lll}\text { Borrador } 1 & \text { Borrador } 2 & \text { Versión final } \\ \text { Os Ídolos que } & \text { Os Ídolos que } & \text { Os Ídolos que } \\ \text { Améi tanto Tempo } & \text { Améi tanto Tempo } & \text { Amara tanto tempo } \\ & & \text { (LXIX) }\end{array}$

Por último, Castro escolle de xeito consistente termos galegos afastados do castelán ou que non teñen equivalente nesta lingua. A intencionalidade e reflexión sobre o uso destas formas vese claramente no estudo dos seus borradores previos, nos que se percibe a evolución de formas máis similares ás castelás cara a palabras máis inequivocamente galegas na súa tradución, como se ve nestes exemplos:

$\begin{array}{lllll}\text { Estrofa } & \text { Versión inglesa } & \text { Borrador } 1 & \text { Borrador } 2 & \text { Versión final } \\ \text { III } & \text { Stay } & \text { Estancia } & \text { Estada } & \text { Estada } \\ \text { XI } & \text { Here with } & \text { Xunto (de) } & \text { Cabo (de) } & \text { Cabo (de) } \\ \text { XI } & \text { Enow } & \text { Sería (bastante) } & \text { Abondaría } & \text { Abondaría }\end{array}$




$\begin{array}{lllll}\text { XII } & \text { Think } & \text { Pensan } & \text { Coidan } & \text { Coidan } \\ \text { XVIII } & \text { Red } & \text { Roxa } & \text { Vermella } & \text { Vermella } \\ \text { XVIII } & \text { Lap } & \text { Regazo } & \text { Colo } & \text { Colo } \\ \text { XL } & \text { Carouse } & \text { Festa } & \text { Troula } & \text { Troula } \\ \text { XLII } & \text { Stealing } & \text { Silenzosa } & \text { Silandeira } & \text { Silandeira } \\ \text { XLII } & \text { Shoulder } & \text { Hombro } & \text { Hombreira } & \text { Hombreira } \\ \text { XLIV } & \text { Slay } & \text { Pena } & \text { Mágoa } & \text { Mágoa } \\ \text { LIX } & \text { Clay } & \text { Barro } & \text { Arxila } & \text { Arxila } \\ \text { LXVIII } & \text { Fling up } & \text { Exhale } & \text { Espalle } & \text { Espalle } \\ \text { LXVIII } & \text { Overtaken } & \text { Embriagado } & \text { Conquerido } & \text { Conquerido }\end{array}$

Vemos, polo tanto, un claro compromiso por parte de Castro de mostrar a validez do galego como lingua de cultura e de dignificar a cultura galega representándoa na versión galega. Castro utiliza dúas estratexias contrarias mais complementarias na súa tradución. Por unha banda, nas cuestións máis relacionadas cos referentes culturais característicos da cultura de orixe queda claro que o tradutor busca un achegamento ao texto orixinal: así, os nomes de referentes culturais persas específicos non se traducen senón que se manteñen e se explican no prefacio e nas notas, de xeito que a experiencia da cultura do orixinal sexa máis inmersiva. Por outra banda, unha análise detallada do texto mostra que a maior parte das estratexias a nivel micro son moi similares ás que presentara en textos anteriores, estudados por Silvia Vázquez Fernández (2013) ou Elisa Serra Porteiro (2015). Coas súas escollas tradutoras, Castro busca dignificar a lingua galega oral —utilizando un rexistro máis coloquial que o orixinal—, mentres que, coa súa vontade de diferenciación lingüística — co uso de expresións e estruturas exclusiva ou tipicamente galegas - e cultural — coa súa escolla de introducir elementos da cultural galega, como o pazo, no texto- Castro proba a existencia do galego como 
lingua e pon distancia entre Galicia e a forza considerada centrípeta do Estado español. A súa intencionalidade de dignificar e promover a lingua e a cultura galegas queda clara na análise das súas estratexias tradutoras e supón un exemplo moi relevante da importancia do estudo do papel da ideoloxía e o activismo nas traducións. Coa súa selección de estruturas gramaticais e sintácticas específicas da lingua galega, a súa adición de referentes culturais galegos típicos para eliminar as posibles influencias castelás do texto e a coloquialización do poema co obxectivo de defender a lingua oral galega, Plácido Castro segue claramente o obxectivo de Grial de promover e dignificar a lingua e de reivindicar e reconstruír a identidade cultural galega. 


\section{REFERENCIAS BIBLIOGRÁFICAS}

Álvarez Lugrís, A. (2005): «Literatura, identidade, nación e tradución na Xeración Nós», en M. a D. Penas (coord.), A identidade galega e irlandesa a través dos textos, Santiago de Compostela, Universidade.

Castro, P. (1928a; 2013): Un galego en Irlanda, Cambados, Fundación Plácido Castro.

CASTRO, P. (1928b): «Cosmopolitas ou "casteláns de imitación”?», traducido por Daniel Landesa Porras, El Pueblo Gallego 15 set., dispoñible na Fundación Plácido Castro: http://www.igadi.org/fundacion_placido_castro/epg_cosmopolitas_ou_castelans_de_imitacion.htm [última visita 28/07/2019].

Castro, P. (1965): «As Rubáyiát de Omar Kayyám», Grial, 8, 159-188.

DASILVA, X. M. (2013): "La traducción al gallego y la censura franquista», Quaderns. Revista de Traducció, 20, 17-29.

Fernández del Riego, F. (n.d.): Carta a Xosé Ramón Fernández-Oxea, dispoñible na biblioteca da Fundación Penzol, Vigo.

FERnÁndez RodríGueZ, A. (2012): «Traducciones en publicaciones periódicas gallegas (1940-1975). El italiano como lengua fuente», Transfer, VII:1-2, 172-185.

Garrido Vilariño, X. M. / A. Luna Alonso (1999): «A revista Grial, introductora de literaturas alleas: panorama das traduccións ó galego (ámbito francófono)», en Anovar-anosar, estudios de traducción e interpretación, vol. 2, 85-96.

GraY, E. (2001): «Forgetting FitzGerald's Rubáiyát», Studies in English Literature, 1500-1900, 41:4, 765-783.

LEFEVERE, A. (1992): Translation, Rewriting, and the manipulation of Literary Fame, Londres / Nova York, Routledge.

LunA, A. (2012): «La revista Grial como importadora de textos italianos (1951-1975)», Transfer, VII:1-2, 186-197.

McKevitt, K. (2003): Leabhar Gabhala, Yeats, and Joyce: The Reception and Translation of Irish Literature in Nós and A Nosa Terra in Galicia (1918-1936). Tese de doutoramento sen publicar. Oxford, Queen's College.

Millán VARELA, C. (1998): Literary Translation in Galician: Appropriating James Joyce. Tese de doutoramento sen publicar. Universidade de Birmingham.

Noia Campos, M. C. (1995): «Historia da traducción en Galicia no marco da cultura europea», Viceversa, $1,13-62$.

Nós (1922): «Os homes, os feitos, as verbas», Nós, 31 xaneiro 1917.

REAL PÉREZ, B. (2001): «A tradución e os textos traducidos ó galego no período 1907-1936», Viceversa, 6, 9-36.

Serra Porteiro, E. (2015): Performing Irishness: translations of Irish drama for the Galician stage (1921-2011). Tese de doutoramento sen publicar. Universidade de Cork.

Toro Santos, A. R. (ed.) (1994): Galicia desde Londres. Galicia, Gran Bretaña e Irlanda nos programas galegos da BBC (1947-1956), A Coruña / Santiago de Compostela, Tambre / Xunta de Galicia.

VÁZQUEZ FERnÁNDEZ, S. (2013): Translation, Minority and national Identity. The Translation/Appropriation of W. B. Yeats in Galicia (1920-1935). Tese de doutoramento sen publicar. Universidade de Exeter.

Venuti, L. (2013): Translation Changes Everything: Theory and Practice, Nova York, Routledge.

VILAVEDRA, D. (1999): Historia da literatura galega. Vigo: Galaxia.

YeAts, W. B. (1935): Dous folk-dramas de W. B. Yeats. [Traducidos por Plácido Castro, Antón Vilar Ponte e Ramón Vilar Ponte]. Santiago de Compostela, Nós. 


\title{
PLÁCIDO R. CASTRO, TRADUTOR E ANGLISTA DA GALEGUIDADE NAS RUBÁIYÁT ${ }^{1}$
}

\author{
María Jesús Lorenzo Modia \\ Universidade da Coruña
}

DOI: $10.17075 /$ vipc.2020.002

\footnotetext{
${ }^{1}$ Este traballo foi realizado co apoio financeiro dos seguintes proxectos e institucións, que por ese medio se recoñecen: «Rede de lingua e Literatura inglesa e Identidade III»(ED431D2017/17), Xunta de Galicia; Proxecto de investigación «Eco-Fictions» (Ministerio de Economía y Competitividad / ERDF, FEDER, FEM2015-66937-P); Proxecto de investigación «Tropo animal» PGC-2018-093545-B100; Proxecto de Investigación "Aesthetics, Ethics and Strategics of the New Migratory Cartographies and Transcultural Identities in Twenty-First-Century Literature(s) in English» (PID2019-109582GB-I00), Ministerio de Ciencia, Innovación y Universidades -MCIU/Agencia Estatal de Investigación -AEI-/Fondo Europeo de Desarrollo Regional -FEDER-/UE; e polo Grupo de investigación de Lingua e Literatura inglesa moderna e contemporánea, CLIN, UDC.
} 

Plácido Ramón Castro del Río é un intelectual galego nado no ano 1902 e que faleceu á idade de sesenta e cinco anos en Cambados, onde exerceu como profesor. A súa tarefa foi a dunha persoa formada en Escocia que volveu a Galicia cun proxecto de divulgación en lingua galega de textos anglófonos de gran relevancia para converter o galego nunha lingua culta. O seu labor como tradutor combínase co de antólogo e divulgador das literaturas en lingua inglesa procedentes de Inglaterra, mais tamén de Gales e Irlanda, e mesmo de textos do antigo imperio persa publicados en inglés e que el verteu ao galego coa finalidade de que se coñecesen nesta lingua culturas europeas e mesmo asiáticas, ás cales el tivera acceso a través do inglés.

Un dos seus primeiros traballos foi, xunto cos irmáns Antón (1881-1936) e Ramón Villar Ponte (1890-1953), a tradución para o galego de Dous folk-dramas (1935) do poeta irlandés William Butler Yeats (1865-1939), que posteriormente foi publicada en Vigo como Dous dramas populares (1977). Inclúe Catuxa Ni Houlihan e $O$ pais da saudade (Cathleen Ni Houlihan e The Land of Heart's Desire). Neses textos únense o simbolismo místico e onírico do imaxinario tradicional irlandés. Estas claves están presentes no Teatro da Abadía da capital irlandesa, fundado en 1904, e que foran plasmadas no denominado rexurdimento de Eirín da man da condesa Constance Markievicz, de familia con orixe polaca e coñecida como Lady Gregory (1868-1927). A relación literaria e política entre Yeats e a intelectual e activista provén da infancia xa que as familias tiñan vínculos de amizade.

É extraordinariamente rechamante a escolla por parte de Castro deste autor angloirlandés, que pertencía á minoría protestante que controlara o país desde o século XVII, mais que se declarara irlandés xusto despois da Guerra de Independencia do Reino Unido, que durou desde 1916 a 1922. W. B. Yeats é conside- 
rado un dos grandes poetas do século XX, e como dramaturgo foi unha das figuras máis representativas do rexurdimento literario (Irish Literary Revival) e un dos fundadores do Abbey Theatre ou Teatro Nacional Irlandés. En recoñecemento ao seu labor, Yeats foi galardoado co Premio Nobel de Literatura en 1923 e tivo tamén unha dimensión política na construción do novo Estado exercendo como senador. Yeats considerou o movemento teatral de Irlanda como a cerna da súa literatura, non só para o facer merecedor do galardón, senón tamén pola transcendencia que tiña no pobo irlandés que non tiña acceso á poesía. O gran público só tiña oportunidade de asistir á representación de obras de orixe inglesa, e non a aquelas que presentasen un discurso irlandés de seu. O galardoado sentíase representante do nacionalismo irlandés e da independencia cultural da nación, como indicara en Suecia no seu discurso de toma de posesión:

[...] the great mass of our people, accustomed to interminable political speeches, read little, and so from the very start we felt that we must have a theatre of our own. The theatres of Dublin had nothing about them that we could call our own. They were empty buildings hired by the English travelling companies and we wanted Irish plays and Irish players. When we thought of these plays we thought of everything that was romantic and poetical, for the nationalism we had called up - like that every generation had called up in moments of discouragement - was romantic and poetical. It was not, however, until I met in 1896 Lady Gregory, a member of an old Galway family, who had spent her life between two Galway houses, the house where she was born and the house into which she was married, that such a theatre became possible (Nobel Lecture s. p.). O groso da nosa xente, afeita aos inacabables discursos políticos, le pouco, e así, desde o primeiro intre sentimos que cumpría ter un teatro de noso. Os teatros de Dublín non tiñan nada que puidésemos chamar propio. Eran edificios baleiros, alugados por compañías itinerantes inglesas, e nós queriamos obras de teatro irlandesas e actores irlandeses. Cando pensabamos nestas obras pensabamos en todo aquilo que era romántico e poético, xa que o nacionalismo que nós invocaramos (como o que todas as xeracións tiñan invocado en momentos de desalento) era romántico e poético. Non foi, con todo, 
ata coñecer en 1896 a Lady Gregory, membro dunha antiga familia de Galway que pasara a súa vida entre dúas casas de Galway, a casa onde nacera e a casa a que veu pertencer por matrimonio, que un teatro así foi posible (Conferencia da concesión do Premio Nobel, tradución propia).

Para comprendermos no século XXI a figura de Plácido R. Castro como tradutor hai que enfocalo desde un punto de vista interdisciplinar, tendo en conta tanto o contexto político e intelectual europeo do seu momento coma as perspectivas críticas contemporáneas. Castro demostrou coñecer moi ben a súa época mediante a escolla de textos para traducir. Á par disto tiña unha gran conexión cos intelectuais galegos da altura, nomeadamente coa coñecida como xeración Nós, cuxa editora publica a tradución dos dramas de Yeats e que xa viña dando a coñecer textos de autores en lingua inglesa. De feito, un destes dramas, Cathleen ni Houlihan, xa fora traducido por Antón Villar Ponte e publicado na revista Nós en 1921 (vol. 8, 5/12: 6-13), aínda que non se precisa a lingua de orixe. Por iso pode resultar significativo analizar o título completo da obra en que Plácido R. Castro participa: Dous folk-dramas. Vertidos á lingua galega directamente do inglés por Plácido R. Castro e os irmáns Vilar Ponte, con licencia do autor. Nel indícase con claridade que a versión é realizada directamente do inglés e non doutra lingua nin cunha versión intermedia dun idioma diferente, como probablemente lle sucedera a Antón Villar Ponte. Tamén se indica que o texto é dado ao prelo coa autorización do autor irlandés, cousa que non foran quen de conseguir diversos tradutores que o intentaran con anterioridade, por exemplo Juan Ramón Jiménez e Zenobia Camprubí (González Ródenas 2005: 68).

Outro caso relevante pola súa recepción en Galicia é o do irlandés James Joyce, que se autoexilia porque non pode soportar a cativa atmosfera relixiosa e política do seu país, mais que dedica toda a súa vida e a súa obra a escribir sobre Irlanda. Así, no día 15 de agosto do ano 1926, Ramón Otero Pedrayo publica xa en Nós (núm. 32, pp. 3-11) fragmentos en galego do Ulysses joyceano, que vira a luz en París en 1922, antes de que saísen versións noutras linguas penin- 
sulares. Posteriormente Vicente Risco dá ao prelo 'Dedalus en Compostela' o 25 de xullo do 1929 (Nós, núm. 67, pp. 123-29), que conta cunha edición posterior, de 1961, da Editorial Galaxia, e que foi traducido ao inglés e ao castelán nunha viaxe de ida e volta (Lorenzo-Modia / Clark 1997).

A influencia do novo estado libre de Irlanda é fundamental para estes escritores galegos das Irmandades da Fala. Son precursores dun interese pola cultura e a literatura deste novo país independente, que culminaría co que hoxe se coñece como estudos irlandeses, e que aínda tardaría medio século en florear. Estes estudos poderían estar simbolizados polo traballo do académico Declan Kiberd, titulado simbolicamente Inventing Ireland (1996) (Inventando Irlanda), no que se reflicte a idea de que o canon literario irlandés aínda se está a construír a finais do século XX. Isto tamén acontece coas historias, guías e antoloxías da literatura irlandesa que se publicaron por vez primeira neste período finisecular e tamén a inicios da centuria presente. Como exemplo pódense tomar as seguintes: A. Norman Jeffares, A Pocket History of Irish Literature (1997); Robert Welsh e Bruce Stewart (eds.), The Oxford Companion to Irish Literature (1996); Julia M. Wright, Irish Literature, 1750-1900: An Anthology (2008); Margaret Kelleher e Patrick O'Leary (eds.), The Cambridge History of Irish Literature (2006), e Stephen Regan (ed.), Irish Writing: An Anthology of Irish Literature in English 1789-1939 (2004).

Mais un enfoque imprescindible para a comprensión da transmisión das obras dunha cultura a outra son os estudos de tradución en tanto que traducir é reescribir transculturalmente, isto é, crear un novo texto nun contexto diferente (Toury 1980, Hermans 2006, Lefevere 1992). Como indica María del Carmen África Vidal no seu libro Traducción, manipulación, desconstrucción, de 1995, a manipulación é imprescindible e debe entenderse no sentido positivo de traballar sobre un texto para que no idioma meta resulte como propio e non teña o efecto de ser culturalmente alleo. Iso é o que consegue Castro del Río (e os irmáns Villar Ponte) coas obras teatrais de Yeats e acada o obxectivo desexado desde o inicio da súa carreira como tradutor. 
Outra das perspectivas críticas necesarias para abordarmos a figura do escritor de Corcubión é a dos estudos poscoloniais. Castro xa repara na descolonización de Irlanda, que está tratando de conseguir a súa reunificación, e moitas das súas escollas de autores para ser traducidos son de escritores que proceden das diferentes nacións do Reino Unido: Irlanda, Gales e inclusive Cornualles. Os críticos contemporáneos falan da hibridación e de sentimentos complexos en zonas descolonizadas, mesmo en Irlanda, nos cales un Yeats procedente dunha familia angloirlandesa protestante pode aglutinar unha maioría católica que se subleva contra o que representan os ingleses. Son referentes nos estudos poscoloniais o palestino catedrático nos Estados Unidos Edward Said, na súa obra seminal Orientalism (1990), ou Gayatri Spivak co seu artigo "Translation as Culture» (1999) sobre a tradución e a súa función na cultura, tan pertinente para o noso escritor, ou o anglohindú Homi Bhabha, que estuda a hibridación cultural (2013).

Por último, para comprendermos o percorrido do texto das Rubáiyát do poeta persa Omar Kháyyám e da súa tradución para o galego por Plácido R. Castro, hai que analizar que todo comeza coa perspectiva do receptor, que o considera interesante para a súa transmisión a outra lingua. Isto coñécese como estudos ou estética da recepción literaria. Foron Wolfrang Iser $(1990,1991)$ e Hans Robert Jauss (1992) os que desde as universidades alemás puxeron en valor a función do público lector na transmisión da literatura e no interese en que determinados textos sexan traducidos e lidos noutras culturas.

Tendo en conta estes supostos, pódese dicir sen temer trabucarse que Plácido Castro é mais ca un tradutor: é o anglista da galeguidade. Entre os anos 1935 e 1965 non hai outro caso de tradutor para o galego tan coñecedor da cultura anglosaxoa coma este. Actúa como intelectual que ten unha axenda cultural e mesmo teórica que se anticipa ao seu tempo. Así, verte para o galego poemas de diferentes autores e autoras relevantes no mundo anglosaxón tanto do seu tempo coma precedentes e dáos a coñecer no ano 1949 na Editorial Alborada de Bos Aires da man de Lois Tobío e Fernando Delgado Gurriarán. O interese contem- 
poráneo desta publicación vese reflectido pola reedición desta obra Poesía inglesa e francesa vertida ao galego, pola Editorial Galaxia en 2004.

Ten especial valor a tradución e estudo comparativo que fai da poeta simbolista inglesa Christina Rossetti (1830-1894), que compara coa galega Rosalía de Castro (1837-1885), traballo que foi publicado pola súa neta en 1997. Tamén é significativo o canon literario do que traduce, no que non faltan autores irlandeses mostrando a importancia de Irlanda como espello en que se ollar, por exemplo os textos asinados como AE, siglas que corresponden ao escritor George Russell (1867-1935), ou os escritos de Padraic Colum (1881-1972). Tampouco descoida Castro del Río outras realidades poéticas como a do país de Gales, representado por W. H. Davies (1871-1940), ou da propia Inglaterra con Walter de la Mare (1873-1956), John Masefield (1878-1967) ou A. E. Housman (1859-1936).

Como sabemos, no cume da súa carreira literaria e profesional, en 1965, Plácido Castro publica a tradución ao galego das Rubáiyát de Omar Kháyyám, astrónomo-poeta que viviu nos séculos XI e XII (1048-1131), no actual Paquistán, territorio que pertencía daquela ao Imperio persa (Teimourian). Para este fin Castro sérvese da primeira versión inglesa de Edward FitzGerald, publicada en Londres en 1859. A versión galega sae do prelo para conmemorar o centenario da publicación das cuartetas de Kháyyám en inglés. A obra continúa a se publicar na actualidade en inglés, en galego e en moitas linguas do mundo nas editoriais de maior difusión internacional e conta mesmo con edicións críticas en inglés, como por exemplo as editadas en 1997 por Christopher Decker, da Universidade de Virxinia, ou a de Daniel Karlin en Oxford University Press en 2009. Igualmente, convén subliñarmos a importancia da influencia deste texto altomedieval en autores posteriores da literatura en lingua inglesa como James Joyce, Nevil Shute, James Michener, Eugene O’Neill e Bernard O’Donoghue (Lorenzo-Modia 2006: 256).

Existen moitos outros escritores e artistas anglosaxóns que enveredaron o camiño de Omar Kháyyám. Citaremos a seguir só algúns dos contemporáneos 
máis salientables. Un dos artistas máis polifacéticos e reverenciados no período vitoriano foi William Morris (1832-1896). Morris e Edward Burne-Jones elaboraron en 1872 unha edición ilustrada da obra, que máis tarde traduciría Plácido Ramón Castro e que tería unha gran difusión en todos os países de fala inglesa. Nela, estes artistas tomaron como símbolo as plumas dos pavos reais, que aínda hoxe figuran na capa da edición de Oxford.

Para sermos quen de calibrar o interese desta obra non só polos seus textos, senón tamén polas ilustracións con que se ornou desde o século XII, cómpre revisarmos as diferentes edicións. Baste nesta ocasión co exemplo do libro xoia elaborado polos impresores George Sutcliffe e Francis Sangorski e polo ilustrador Eidu Vedder por encarga do libreiro londiniense Henry Sotheran. Estiveron a traballar nel desde 1909 ata 1912, ano en que viu a luz. Segundo Joobin Bekhrad, esta edición especial estaba ornamentada cunhas mil pedras preciosas e semipreciosas, entre as cales se atopaban rubís, turquesas e esmeraldas; as súas 600 páxinas de pergameo fino foron cubertas con pan de ouro de 22 quilates e con incrustacións de marfil, prata e outros metais (s. p.). Despois de ser sacado a poxa en Sotheby's en Londres por 465 libras, o texto tiña que ser enviado aos Estados Unidos, mais non foi posible facelo no prazo previsto polos elevados custos dos seguros para o volume; só foi embarcado na fatídica viaxe inaugural emprendida polo vapor Titanic no ano 1912, no cal, desafortunadamente, se perdeu este exemplar único (Eaton / Haas 1987: 131; Bekhrad 2018: s. p.). Stanley Bray, sobriño de Francis Sangorski, reproduciu o libro cun traballo de seis anos, mais, como se estivese mal fadado, foi novamente destruído nos bombardeos da Segunda Guerra Mundial na capital británica (Bekhrad s. p.). A tenacidade de Bray fixo que emprendese de novo a tarefa despois da guerra, mais desta volta a edición demorou corenta anos de traballo intermitente e foi entregada como doazón á Biblioteca Británica (Bekhrad s. p.). Esta fascinante historia de abnegación para difundir versións ilustradas das Rubáiyát puido estar detrás da motivación de Plácido R. Castro para verter ao galego o texto. 
Outro dos elementos que quizais influíse no tradutor é o grande interese que moitos escritores mostraron na obra, tanto do que se denomina alta cultura coma dos niveis máis populares, xa que o poemario foi utilizado como texto docente nas escolas de fala inglesa nos dous lados do océano Atlántico. O autor francolibanés Amin Maalouf gañou o Premio Goncourt de novela de 1993 coa ficción titulada Samarcande (1988), que se basea na denominada 'Edición Marabilla' das Rubáiyát ilustrada con xoias.

Este poemario oriental que pondera o carpe diem foi valorizado por numerosos escritores de diferentes países, especialmente no período vitoriano. O propio Oscar Wilde, na novela O retrato de Dorian Gray (1891), fai que Lord Henry se refira a Omar Kháyyám como o sabio rei do hedonismo «wise Omar» (86). Outro dos autores que incorpora a obra e o autor das Rubáiyát é o norteamericano Jack London (1876-1916) na obra O lobo de mar (1904), na que a fai tema de discusión entre dous personaxes do capítulo XI que debaten sobre a interpretación dunha cuarteta. O dramaturgo irlandés Sean O'Casey tamén fai referencia ao texto a través do personaxe de Donal Davoren, que incorpora algúns dos versos das Rubáiyát na obra The Shadow of a Gunman (1923): "grasp this sorry scheme of things entire, / and mould life nearer to the heart's desire» (Karlin 2009: LXXIII, 52). Hai varios escritores que toman un fragmento das Rubáiyát para o propio título das súas obras. Un dos casos coñecidos é o da prolífica autora norteamericana de nome Edith Newbold Jones, coñecida literariamente como Edith Wharton (1862-1937), que no ano 1904 deu ao prelo The Moving Finger ( $O$ dedo que se move). Agatha Christie é tamén unha das escritoras que utiliza o mesmo título para unha das súas obras de suspense, que publicou por primeira vez precisamente nos Estados Unidos en 1942. É este mesmo sintagma o utilizado de novo por Stephen King no ano 1990 para o título dun conto. A tal cuarteta corresponde a unha das máis citadas do poeta persa por se referir á permanencia da palabra escrita e noutros autores aparece o texto completo dela. Así, con posterioridade á tradución de Plácido R. Castro, a obra segue a ser mencionada nos textos literarios e en diferentes manifestacións culturais e cívi- 
cas. Na novela do norteamericano Kurt Vonnegut titulada Breakfast of Champions or Goodbye Blue Monday (Almorzo de campións ou adeus luns azul) (1973), un dos personaxes, Dwayne Hoover, rememora a coñecida estrofa sobre o poder das palabras escritas que memorizara na escola:

The Moving Finger writes; and, having writ

Moves on: not all thy Piety nor Wit

Shall lure it back to cancel half a Line,

Not all thy Tears wash out a word of it. (Karlin 2009: LI, 41)

O Dedo que se move escrebe, e vaise logo,

E nin túa Piedade, nin teu Inxenio todo,

o enmeigan pra que volte e borre meia Liña,

nin lavas unha Verba con todolos teus Choros. (Castro en Toro Santos 1996: 33)

Este poema é tan coñecido no mundo de fala inglesa que tamén se cita en discursos de diferentes oradores. Un caso paradigmático é o de Martin Luther King Jr., que no seu parlamento do día 4 de abril de 1967, titulado «Beyond Vietnam» (Mais aló do Vietnam) (s. p.), utilizara xa a mesma citación: «It is time for all people of conscience to call upon America to come back home. Come home America. Omar Khayyám is right 'The moving finger writes and having writ, moves on.'» (É tempo de que toda a xente con conciencia de América lles diga que volvan á casa. América volve. Omar Kháyyám ten razón 'O Dedo que se move escrebe, e vaise logo'). Posteriormente, no discurso do presidente Bill Clinton aos reporteiros no xardín das rosas da Casa Branca o 11 de decembro de 1998, uns minutos antes de que o Comité Xudicial da Cámara americana votase sobre a súa acusación (Impeachment), dixo o seguinte: «An old and dear friend of mine recently sent me the wisdom of a poet who wrote: 'The moving finger writes and having writ, moves on. Nor all your piety nor wit shall lure it back to cancel half a line. Nor all your tears wash out a word of it.'» (Un vello 
amigo mandoume hai pouco a sabedoría dun poeta que escribiu: O Dedo que se move escrebe, e vaise logo, E nin túa Piedade, nin teu Inxenio todo, o enmeigan pra que volte e borre meia Liña, nin lavas unha Verba con todolos teus Choros) (s. p.). O poeta que nesta ocasión Clinton non cita é Omar Kháyyám e faino precisamente coa mesma estrofa que fora mencionada por Luther King.

No mundo hispánico hai tamén moitos escritores que se fan eco deste poema nas súas obras. Entre os autores en español que citan as Rubáiyát de Kháyyám está o galardoado co Premio Nobel de Literatura Juan Ramón Jiménez, que as inclúe en Platero y yo: "Nos hemos quedado solos Platero y yo. ¡Qué paz! ¡Qué pureza! ¡Qué bienestar! Dejo a Platero en el prado alto y yo me echo, bajo un pino lleno de pájaros que no se van, a leer. Omar Khayyam... En el silencio que queda entre dos repiques [...]» (cap. XXXVII «Domingo»). Esta obra foi traducida para o galego como Platero e mais eu en 1990 por Manuel Beiras García, coñecido polo pseudónimo Eubensei.

Outro dos escritores senlleiros que citan o poeta persa é o arxentino Jorge Luis Borges (1899-1986). No seu libro de ensaios Otras inquisiciones (1952) inclúe un titulado «El enigma de Edward Fitzgerald», no que discute o labor do tradutor irlandés Edward FitzGerald. Tamén trata dos versos de Omar Kháyyám no poema «El ajedrez» de El hacedor (1960) e en Elogio de la sombra (1969), xustamente no titulado "Rubaiyat», composto por estrofas de catro versos (14). O interese de Borges polo poeta persa xa provén dunha tradución realizada polo seu pai, o escritor Jorge Guillermo Borges (García 2015: s. p.).

En español as Rubáiyát do poeta persa foron cantadas por Camarón de la Isla en La leyenda del tiempo (1979), nunha versión de «Viejo mundo» de José María Lopez Sanfeliú, máis coñecido como Kiko Veneno, que veu namorado delas á súa volta dos Estados Unidos, pola repercusión xa mencionada de Omar Kháyyám na cultura anglosaxoa e nos seus poetas (Mora / Gamboa, en Camarón 1979b: 45-52).

$\mathrm{Na}$ cultura galega existen moitas edicións e versións posteriores que homenaxean a Castro pola súa visión como tradutor e unha delas é a tradución desde o 
francés de Miguel González Garcés (1992). A seguinte é a versión bilingüe dada ao prelo por Antonio Raúl de Toro en Espiral Maior (1996), que foi complementada por unha nova edición galega na Editora Bahía (2010) e ilustrada polo pintor Javier Correa Corredoira; esta réndelles tributo ás edicións manuscritas do libro desde a súa orixe e que se continúan a publicar ata o século XXI co fin de reflectiren a cultura oriental que lles deu orixe. Trátase probablemente dunha lembranza á intención do propio tradutor, que tiña o proxecto dunha edición ilustrada do pintor de Marín, Manuel Torres, segundo consta na documentación escrita dunha emisión radial de Luís Seoane do 2 de abril de 1961, arquivado na Fundación que leva o seu nome.

O escritor de Corcubión tentou crear, mediante o labor de tradutor desde a súa tarefa nas Irmandades da Fala ata o seu pasamento, a translación á cultura de Galicia dos autores e autoras valorizados na cultura anglosaxoa (Lorenzo-Modia e Pérez Janeiro 1994: 255-260). Centrouse, por unha banda, nos poetas da segunda metade da época vitoriana que puxeron en cuestión os valores imperantes da Inglaterra colonial. Por outra banda, hai que notar a creación dun canon literario en tradución da lingua inglesa que foi peneirada igualmente pola súa querenza por Irlanda, con versións de Yeats e Lady Gregory, entre outros, xunto á tradución do tamén irlandés Edward FitzGerald. Todos eles colaboraran na formación da literatura irlandesa da nova república independente. Plácido R. Castro del Río considerou imprescindible manter a bandeira da lingua e cultura propias nunha etapa de escurantismo grande. A súa tradución das Rubáiyát pode describirse mediante as palabras que el mesmo empregou para definir o texto de FitzGerald: «unha especie de bandeira, ergueita polos que loitaban, na vida social e nas artes, contra os convencionalismos e a 'respectabilidade'» (1965, 167). 


\section{REFERENCIAS BIBLIOGRÁFICAS}

ARIAS, Valentín / Alberto A. Lugrís (2005): «Significado e importancia de Plácido Castro no panorama da tradución en Galicia», en Igadi na Rede / Fundación Plácido Castro - VI Conferencia Anual Plácido Castro, 30 de xaneiro de 2005, actualizado (http://www.igadi.org/fundacion_placido_castro/vi_conferencia_anual.htm) [última consulta: 27 de abril de 2005].

AvErY, Peter (1981): «Introduction», en The Ruba'iyat of Omar Khayyam, Londres, Penguin, 9-43.

Avery, Peter / John Heath-Stubbs (trads.) (1981): The Ruba'iyat of Omar Khayyam, Londres, Penguin.

BEKHRAD, Joobin (2018): «The Rubaiyat: History's Most Luxurious Book of Poetry?», BBC Literature, 11-I-2018， s. p. (http://www.bbc.com/culture/story/20180111-the-rubaiyat-historys-most-luxurious -book-of-poetry).

BHABHA, Homi (2013): Nuevas minorías, nuevos derechos: notas sobre cosmopolitismos vernáculos, Bos Aires, Siglo XXI.

BORGES, Jorge Luis (1952): «El enigma de Edward FitzGerald», en Otras inquisiciones, Bos Aires, Sur.

BORGES, Jorge Luis (1969): Elogio de la sombra, Bos Aires, Emecé.

Borges, Jorge Luis (1972 [1960]): El hacedor, Madrid, Alianza.

Camarón (DE la Isla) / José María López Sanfeliú (Kiko Veneno) (1979a): «Viejo mundo», en La leyenda del tiempo.

CAMARÓN (DE LA Isla) (1979b): «Viejo mundo», en La leyenda del tiempo. [Introd. Miguel Mora e Manuel Gamboa]. Madrid, El País, 2008 (https://youtu.be/Q1x3E7QSvHU).

Castro del Río, Plácido R. (1965): «As Rubáyiát de Omar Kayyám, o astrónomo-poeta de Persia», Grial, 8, 159-188.

Castro del Río, Plácido R. (1997): Mostras da poesía de Christina Rossetti vertidas do inglés ó galego, Cambados, Gráficas Salnés.

Castro del Río, Plácido R. / Lois Tobío Fernández / F. M. Delgado Gurriarán (trads.) (1949): Poesia inglesa e francesa vertida ao galego, Bos Aires, Editorial Alborada. Vigo, Galaxia, 2004.

Christie, Agatha (1942): The Moving Finger, Nova York, Dodd Mead.

CuInton, Bill (1998): Discurso na Casa Branca, 11-XII-1998 (http://www.historyplace.com/speeches/ clinton-rose-garden.htm).

DAVIS, Dick (1989): «Introduction», en Edward Fitzgerald: Rubáiyát of Omar Khayyám, Londres, Penguin, $1-42$.

DeCKer, Christopher (ed.) (1997): Edward FitzGerald. Rubáiyát of Omar Khayyám. A Critical Edition, Charlotteville, University P. of Virginia.

Eaton, John P. / Charles A. HaAs (1987): Titanic: Destination Disaster: The Legends and the Reality, Wellingborough, Reino Unido, Patrick Stephen.

FITZGerald, Edward (trad.) (1872): Rubáiyát of Omar Khayyám. [Ilustr. William Morris e Edward BurneJones]. Oxford, Univ. of Oxford, Bodleian Libraries, 2014.

FitzGerald, Edward (1903): Rubáiyát of Omar Khayyám, Londres / Nova York, Routledge / Dutton.

FitzGerald, Edward (1989): Rubáiyát of Omar Khayyám, Londres, Penguin.

FitzGerald, Edward (2010): Rubáiyát de Omar Khayyám. [Ilustr. Javier Correa Corredoira]. Oleiros (A Coruña), Bahía.

García, Carlos (2015): «Borges (padre) y Omar Jayyam (I)», El Trujamán. Revista diaria de traducción, 
19-IX-2015, s. p., Centro Virtual Cervantes, Instituto Cervantes (https://cvc.cervantes.es/trujaman/ anteriores/septiembre_05/19092005.htm).

GonzÁlez Garcés, Miguel (trad.) (1992): Rubayyat de Omar Khayyam, A Coruña, Deputación da Coruña.

GONZÁLEZ RóDENAS, Soledad (2005): Juan Ramón Jiménez a través de su biblioteca: Lecturas y traducciones (1881-1936), Sevilla, Universidad de Sevilla.

Hermans, Theo (2006): Translating Others, Manchester, St. Jerome.

Housman, Laurence E.: «Introduction», en Edward Fitzgerald: The Rubáiyát of Omar Khayyám, Londres I Glasgow, Collins' Clear-Type Press, s. d. [1957], 9-39.

Housman, Laurence E. (ed.) (1957): Edward Fitzgerald: The Rubáiyát of Omar Khayyám, Londres I Glasgow, Collins' Clear-Type Press.

Iser, Wolfrang (1990): The Implied Reader. Patterns of Communication in Prose Fiction from Bunyan to Beckett, Baltimore, The Johns Hopkins University Press.

IsER, Wolfrang (1991): The Act of Reading. A Theory of Aesthetic Response, Baltimore, The Johns Hopkins University Press, 1991.

JAUSS, Hans Robert (1992): Experiencia estética y hermenéutica literaria: ensayos en el campo de la experiencia estética, Madrid, Taurus.

JefFares, A. Norman (1997): A Pocket History of Irish Literature, Dublín, O’Brien Press.

JiméneZ, Juan Ramón (1914): Platero y yo, Madrid, Ediciones de la lectura. Trad. gal. Manuel Beiras García (Eubensei): Platero e mais eu, Sada (A Coruña), Ediciós do Castro, 1990.

KarLIN, Daniel (ed.) (2009): Rubáiyát of Omar Khayyám. [Trad. Edward FitzGerald]. Nova York, Oxford UP.

KelLEHER, Margaret / Patrick O'LeARY (eds.) (2006): The Cambridge History of Irish Literature, Cambridge, CUP.

KiberD, Declan (1996, 1997): Inventing Ireland: The Literature of the Modern Nation, Boston, Harvard UP.

KING, Stephen (1990): «The Moving Finger», The Magazine of Fantasy \& Science Fiction. En Nightmares and Dreamscapes, Nova York, Viking, 1993.

KING JR., Martin Luther (1967): «Beyond Vietnam»(4-IV-1967), Nova York, Stanford University (https://kinginstitute.stanford.edu/king-papers/documents/beyond-vietnam).

LEFEVERE, André (1992): Translation, Rewriting, and the Manipulation of Literary Fame, Londres, Routledge.

Lorenzo-Modia, María Jesús (1997a): «Traducción de Vicente Risco "Dedalus en Compostela: pseudoparáfrasis"», Espéculo. Revista de Estudios Literarios, III:7, 1-11 (https://webs.ucm.es/info/especulo/ numero7/v_risco.htm).

Lorenzo-Modia, María Jesús (1997b): «Stephen Dedalus into Spanish and back into English: Genesis of the Translations», Galician Review, I, 52-61.

Lorenzo-Modia, María Jesús (2006): «Significado e valor da tradución de As Rubáiyát de Omar Khayyám», en Congreso sobre Plácido Castro e o seu tempo, Santiago de Compostela, Xunta de Galicia, 255-271.

Lorenzo-Modia, María Jesús / Purificación Pérez Janeiro (1994): «A traducción da poesía en lingua inglesa ó galego», Grial, 122, 255-60. 
LORENZO-Modia, María Jesús / David Clark (trads.) (1997): «Dedalus in Compostela: a Pseudoparaphrase», Galician Review, I, 62-72.

MaAlouf, Amin (1988): Samarcande, París, Jean Claude Lattés. [Trad. cast. María Concepción García-Loma: Samarcanda, Madrid, Alianza, 2006].

Markievicz, Constance (Lady Gregory) (1979): The Collected Plays, Gerrard's Cross, Colin Smythe.

Michener, James (1949): The Fires of Spring, Nova York, Random House. ('Os lumes da primavera').

O'Casey, Sean (1998): Three Dublin Plays. [Introd. Christopher Murray]. Londres, Faber and Faber.

O'Casey, Sean (1994): Three Plays: Juno and the Paycock; The Shadow of a Gunman; The Plough and the Stars, Londres, Papermac.

O’Donoghue, Bernard (1999): Here nor There, Londres, Chatto \& Windows, ('Aco nin aló').

O’Neill, Eugene (1933): Ah, Wilderness!, Nova York, Random House, ('Ah, Deserto!').

Otero Pedrayo, Ramón (1926): «Anacos da soadísima novela de James Joyce postos en galego do texto inglés por Ramón Otero Pedrayo», Nós, 32 (15-VIII-1926), 3-11.

REGAN, Stephen (ed.) (2004): Irish Writing: An Anthology of Irish Literature in English 1789-1939, Oxford, OUP.

Risco, Vicente (1929): «Dedalus en Compostela», Nós, 67 (25-VII-1929), 123-129. Reeditado Vigo, Editorial Galaxia, 1961.

SAID, Edward (1990): Orientalismo, Madrid, Libertarias Prodhufi.

SEOANE, Luis (1961): «Emisión radial», 2-IV-1961, A Coruña, Fundación Luis Seoane.

Shute, Nevil (1947): The Chequer Board, Londres, Heinemann, ('O taboleiro de cadros').

SPIVAK, Gayatri Chakravorty (1999): "Translation as culture», en Isabel Carrera Suárez et al. (eds.), Translating Cultures, Oviedo / Hebden Bridge (UK), KRK / Dangaroo Press, 17-30.

TeImourian, Hazhir (2010): Omar Jayyam. La biografia definitiva de un genio universal / The definitive biography of a universal genius. [Trad. Laura Herrero Felipe]. Córdoba, Editorial Berenice. (Repertorio Español de Bibliografía Árabe e Islámica).

Toro Santos, Antonio R. de (ed.) (1996): Edward Fitzgerald: As Rubáiyát de Omar Khayyám. Bilingüe (Inglés-Galego). [Introdución e tradución Plácido R. Castro]. A Coruña, Espiral Maior.

Toury, Gideon (1980): In Search of a Theory of Translation, Tel Aviv, Porter Institute for Poetics and Semiotics.

Vidal Claramonte, María del Carmen África (1995): Traducción, manipulación, desconstrucción, Salamanca, Ediciones Colegio de España.

Vonnegut, Kurt (1973): Breakfast of Champions or Goodbye Blue Monday, Nova York, Delacorte P.

Welsh, Robert / Bruce STEWART (eds.) (1996): The Oxford Companion to Irish Literature, Oxford, Clarendon Press.

WHARTON, Edith (2001): Collected Stories 1891-1910, Nova York, Library of America.

WILDE, Oscar (1988): The Picture of Dorian Grey. [Ed. Donald L. Lawler]. Nova York, Norton.

Wright, Julia M. (2008): Irish Literature, 1750-1900: An Anthology, Oxford, Blackwell.

YeAts, W. B. (1903): The Lands of Heart's Desire, Portland (Maine), Thomas B. Mosher (https://archive. org/details/landofheartsdesi00yeatuoft/page/n4).

YeATS, W. B. (1906): Cathleen ni Houlihan, Londres, A. H. Bullen. 
Yeats, W. B. (1921): Cathleen ni Houlihan. [Trad. Antón Vilar Ponte]. Nós. Boletín Mensual da Cultura Galega, 8 (5-12-1921), 6-13.

YeATS, W. B. (1935): Dous folk-dramas. Vertidos á lingua galega directamente do inglés por Plácido R. Castro e os irmáns Vilar Ponte, con licencia do autor, volume LXIX, Santiago de Compostela, Editorial Nós.

Yeats, W. B. (1977): Dous dramas populares. [Trad. Plácido R. Castro e os irmáns Vilar Ponte]. Vigo, Castrelos.

Yeats, W. B. (2019): «Nobel Lecture». NobelPrize.org. Nobel Media AB 2019. 12 xuño 2019 (https:// www.nobelprize.org/prizes/literature/1923/yeats/lecture/). 


\section{PLÁCIDO CASTRO E O XORNALISMO}

César Lorenzo Gil

Xornalista e editor de Biosbardia

DOI: 10.17075/vipc.2020.003 

A análise da obra periodística de Plácido Castro ao longo do tempo representa moi ben como muda (obrigatoriamente) o eixe da actividade simbólica do galeguismo. Se antes da guerra a intención é reivindicar a natureza da substancia política de Galicia, reclamar o seu espazo entre as nacións do mundo e fomentar a autoestima nacional sobre o pivote do autogoberno, logo da guerra, como lle ocorre ao denominado galeguismo interior, ten que flutuar cara á cultura. Xa non é posible reivindicar a Galicia política, de ningún xeito, so pena de cadea ou de morte. É a cultura o único recanto no que Galicia pode seguir viva. Con moitas restricións, perífrases e elipses pero dun xeito tan marcado que este cambio de temón marca aínda hoxe as preocupacións e tics do galeguismo. A propia biografía de Castro pode caricaturizarse en tres momentos moi reveladores: é a figura que consegue o primeiro recoñecemento de Galicia como nación no contexto internacional, é a voz que fala en galego na BBC de Londres, é o promotor da Feira do Albariño de Cambados ou da Romaría Vikinga de Catoira. Este tránsito loxicamente ten pegada nos seus textos escritos.

Plácido Castro asenta a súa práctica xornalística previa á guerra en dous eixes: xornalismo asentado nos datos e un propósito político claro: equiparar a Galicia coas outras nacións do mundo en pé de igualdade.

Xa desde as súas primeiras colaboracións en A Nosa Terra e El Pueblo Gallego durante o período da ditadura de Primo de Rivera, observamos que o xornalismo de opinión que propón se guía por dúas premisas fundamentais: o dato é máis importante ca a sensación. Neste sentido, o seu xornalismo é didáctico. E, ademais, busca argumentar baseándose nunha lóxica dialéctica precisa. É un xornalismo científico, cualificativo que recolle os seus obxectivos: observación, argumentación, hipótese e proposta. 
Para Castro, o método para que a cultura galega se sentise partícipe do contexto mundial pasaba por entender o contexto mundial e participar en todos os escenarios sen complexos. A pesar de que o termo nos pareza moderno, a globalización xa existía, en certa medida, na época de Castro. El mesmo era froito desa globalización se atendemos á súa biografía: nacenza en Galicia, crianza en Gran Bretaña e volta á terra natal. E el mesmo, en varios dos seus artigos, alude ao cambio de dimensións do planeta, por mor dos avances técnicos e tras a experiencia do primeiro conflito bélico que adquiriu o cualificativo de mundial. «Agora — di—xa non é coma antes. A xente viaxa, coñece como viven as demais nacións, fai turismo».

- A primeira área temática que tratou, cronoloxicamente falando, e que cultivou por razóns obvias en moitos momentos, foi Gran Bretaña. Alén de que Castro vivise alá e por razóns profesionais estivese moi atento ao que alí ocorría, hai que atender á importancia do Reino Unido na década de 1920.

Plácido Castro é testemuña privilexiada do inicio do ocaso do Imperio Británico. Hai que recordar que, ata 1918, Gran Bretaña foi a primeira potencia mundial e que na década de 1920, tras a creación do Estado Libre de Irlanda e o aumento da autonomía nalgunhas outras colonias, especificamente Canadá, a República de Suráfrica e Australia, déixase de falar de imperio e pásase a falar de Commonwealth, que en galego ten unha tradución ben familiar: mancomunidade. Son as propias elites británicas as que tutelan e controlan a detonación da súa primacía universal, camuflando no mancomún a súa esfera de influencia, que persiste mal que ben ata hoxe e que consegue manter a salvo a súa relevancia mundial a pesar de que logo da II Guerra Mundial xa se confirma o seu devalo fronte aos Estados Unidos.

Plácido Castro consideraba o modelo político e administrativo do Reino Unido da Gran Bretaña un exemplo. Estaba fascinado pola flexibilidade e pragmatismo das súas institucións. A súa profunda simpatía polo nacionalismo irlandés, escocés ou galés non foi atranco para que gabase a articulación dun 
Estado que era capaz de permitir as diferenzas no seu seo, que naquel momento contaba con varios parlamentos e que, segundo as súas propias palabras, non se opuña á diversidade nacional e lingüística de cada un dos seus territorios. Este optimismo british confrontouno sempre co pesimismo polo centralismo español e a súa ansia por desgaleguizar Galicia.

O interese británico non queda aí. Plácido Castro logrou levar á praxe a tradicional arela do galeguismo desde o seu nacemento a finais do século XIX: evidenciar as ligazóns culturais atlánticas. Eran bos Pondal ou Murguía reivindicando a Galicia celta, rememorando e construíndo mitos, soñando cun pasado común de feliz comunidade. Otero Pedrayo traduciu a Joyce e a revista Nós tivo sempre unha profunda simpatía polas nacións celtas. Mais Castro é o primeiro intelectual galeguista que ten na sola das botas terra das dúas beiras dese mítico Atlántico polo que navegara Breogán. O seu atlantismo, sendo tan entusiasta e intenso coma o do resto dos galeguistas, aséntase nun profundo coñecemento da cultura, da tradición e tamén da literatura contemporánea das nacións británicas. Esa posición de privilexio serviulle para falar das súas poéticas con gran propiedade e dotou de argumentos ese elo entre nós e as illas británicas. Un elo que, non nos enganemos, lle serviu ao galeguismo (e agora pouco se usa, para a miña sorpresa, na praxe dialéctica) como mecanismo estratéxico para superar a dependencia xeográfica con Madrid no intercambio comercial, económico, académico... O atlantismo como porta cara a Europa e a universalidade, o obxectivo constante de Castro durante toda a súa vida.

- Xa en Galicia, Gran Bretaña segue a servirlle a Castro como acicate para espertar a Galicia. Amais de reflexións sobre os problemas derivados do centralismo e das vantaxes do autogoberno, a Castro interésalle o desenvolvemento práctico do país e é por iso polo que bota man das comparacións co que ocorre no Reino Unido. É así cando aproveita que fala de determinados cambios lexislativos en Londres sobre infraestruturas viarias para reclamar unha rede de autoestradas que permitan crear un modelo de transporte público e de mercadorías máis eficiente 
e barato ca o ferroviario. Ou cando repara nos avances de Irlanda na tecnificación turística (con grandes resultados visibles ata hoxe na atracción de visitantes) para reclamar un cambio de perspectiva para converter ese sector en estratéxico no noso país.

- O marco temático e o ton da obra xornalística de Castro que publica en Galicia, como dixemos, mudan totalmente despois da guerra. Mais curiosamente, se houber un lector atento, encontraría o pouso das súas constantes, aínda que fosen esvaídas, sobreentendidas.

Por unha banda, o interese polo británico. Castro publica comentarios (e tamén traducións) de autores, polo xeral clásicos. Pero nótase nel que segue habitualmente a prensa das illas e atende a fenómenos como os Beatles. Tamén atende á actualidade política e sobre todo á idiosincrasia dun país que tamén se enfrontou a un profundo cambio de mentalidade despois de 1945. Antes falaba da lenta reconversión imperial que remata no proceso de descolonización masiva. Mais hai que lembrar que tras o final da II Guerra Mundial Gran Bretaña puxo en práctica un modelo político socialdemócrata durante o cal se nacionalizaron sectores económicos estratéxicos ou se construíron de forma masiva vivendas a prezos accesibles.

Castro tamén volve atender aos propios desafíos da sociedade galega en termos moi concretos, como a el lle gusta. Son interesantes neste último período as súas contribucións á profesionalización do sector turístico. Dixen antes que el foi promotor dalgunhas das celebracións senlleiras do Salnés cuxo modelo foi logo amplamente difundido por toda Galicia. Para Castro este era un máis dos ingredientes que precisaba a industria do turismo para gañar en atractivo e en rendibilidade. Chama a atención que xusto antes do auxe turístico que experimentou a España do sol, Castro xa falaba das potencialidades e perigos desta explotación dos recursos patrimoniais e paisaxísticos. O turismo que el defende era moi moderno para aquel tempo. Sempre cun ollo posto no modelo 
irlandés, propuña valorizar a nosa historia e cultura nunha proposta sustentable e conservadora.

É tamén destacable como Castro buscou complicidades sobreentendidas con dúas figuras chave do galeguismo cuxa evolución persoal non tivo nada que ver coa súa. Os diálogos xornalísticos con Álvaro Cunqueiro e Vicente Risco son de moita valía. 


\title{
PLÁCIDO CASTRO E A PRENSA DA SÚA ÉPOCA
}

\author{
Luís Álvarez Pousa
}

Xornalista e director de Tempos Novos

DOI: 10.17075/vipc.2020.004 

As fontes das que se valen os estudosos de Plácido Castro para descubriren a quen, sen ningunha dúbida, pode ser considerado unha das figuras máis singulares do galeguismo republicano teñen maioritariamente na súa prosa xornalística a súa principal localización. Sendo isto así, calquera achega que os expertos fagan ao seu pensamento político (ao seu ideario ligado aos valores da democracia, o liberalismo e a identidade), ao universalismo e a canto fai del un activo intanxible no discurso e na acción política do galeguismo e do nacionalismo ten forzosamente que explicitar o contido dun mollo de textos publicados entre 1927 e 1967 nunha ducia de publicacións.

Velaí polo que, sobre a relación de Plácido Castro coa prensa neses corenta longos e produtivos anos da súa vida pública, optei non tanto por describir e analizar eses contidos, como por facer ver:

a) o estado da comunicación/prensa de masas e/ou de tendencia (indispensable para a difusión do ideario galeguista e/ou nacionalista que desde o último cuarto do século XIX loitaba por facerse notar en Galicia);

b) a relativa eficacia da cruzada divulgadora á que se entregaron os principais protagonistas do galeguismo e/ou nacionalismo histórico —a intelligentsia galeguista - por mor precisamente das dificultades de poder dispoñer dos medios que a farían social e politicamente operativa;

c) o que non impide que valoremos o heroico esforzo de cantos, como é o caso de Plácido Castro, deixaron testemuño dun movemento cívico, político e cultural, baseado nos valores de democracia e identidade. Especialmente no seu caso, por se tratar dun extraordinario embaixador da causa galega e dun finísimo e culto analista que soubo mirar o mundo desde nós (o seu universalismo integrador). 
No modelo que demos en chamar Sociedade de Cultura e Comunicación de Masas (provocado polos procesos industrializadores) é fundamental o papel vertebrador — político e simbólico— e organizador — social e cultural— da prensa moderna. Nesa dupla función socializadora e política é onde recoñecemos e asumimos que a prensa non só entrega a información que reduce o nivel de incerteza sobre a realidade, senón que tamén produce realidade. E aínda máis: na medida en que proporciona referentes, sentidos e significados que son comúns á sociedade en que asenta e ten incidencia, produce ou coproduce identidade.

Esa tripla función socializadora, política e identitaria que lle apoñemos á prensa moderna sufriu historicamente en Galicia unhas fortísimas limitacións, derivadas das súas propias dependencias estruturais e tamén de factores (sociais, políticos, económicos e culturais) que a viñeron condicionando desde fóra. Quedamos á marxe da revolución industrial que se xerou e desenvolveu no seu momento en Europa, e tardamos en acadar os mínimos niveis educativos ou de alfabetización, por unha banda, e os mínimos de asentamento urbano, pola outra; en definitiva, de case todo o que favorecía nos países do noso contorno europeo, e aínda que máis serodiamente tamén noutros territorios de España, a conformación dunha sociedade e dunha cultura de masas, o caldo de cultivo necesario para que a súa prensa tamén o fose.

Foron numerosas as cabeceiras que se contabilizan nun percorrido que visualiza todo o que o século XIX e o primeiro terzo do século XX deron de si nese terreo. Botando man dos estudos que se fixeron ata agora para avaliar a súa importancia, quérese dicir a súa capacidade para exercer esa tripla función socializadora, política e identitaria, a conclusión á que un chega non é precisamente a mesma que a que podemos tirar dos estudos realizados sobre a prensa de Cataluña ou Madrid nese tempo histórico. O que digo vale tanto para a prensa ideolóxica da que participan as máis variadas tendencias políticas e partidarias, coma para a prensa que máis abertamente asume o ideario dos sucesivos movementos galeguistas e/ou nacionalistas. 
Esta prensa de tendencia galeguista e/ou nacionalista sempre ocupou postos moi baixos na clasificación de publicacións periódicas: non só no periodo neoprovincialista, por mor da deficiente consistencia desta primeira forma do galeguismo político, que ademais se mantivo subordinado ideoloxicamente ao liberalismo español de esquerdas; tamén durante o período rexionalista, no que, pese a que medra en número de cabeceiras (32 en total, iso si, sempre minoritarias e de periodicidade non diaria), rebaixa a súa participación no conxunto de toda a prensa - liberal, conservadora, tradicionalista/católica, republicana, socialista, anarquista, agrarista e outras moitas de tendencia non coñecida (804 en total) ${ }^{1}$. E aínda que coa transformación do rexionalismo en nacionalismo incrementa e cualifica a súa presenza pública nese tempo que vai de 1916 a 1931, non por iso acurta as distancias coa outra prensa comercial ( $L a$ Voz de Galicia, La Región etc., as que na súa maioría aínda perduran hoxe en día) e tamén coa que se diversifica en tendencias, ao non progresar coma os demais no importantísimo e decisivo formato dos xornais (prensa de aparición diaria). Era na súa práctica totalidade prensa de periodicidade semanal, quincenal, mensual...

En realidade, a prensa de tendencia rexionalista e nacionalista que chegou a ter certo peso redúcese na práctica a dúas cabeceiras que, aínda tendo en común ese carácter ou esa tendencia, responden a dous modelos de moi diferente contextura comunicacional e profesional.

A primeira desas dúas cabeceiras que tiveron máis peso é $A$ Nosa Terra (que nacera en 1907 como voceiro dos solidarios, que entre 1916 e 1932 foi o idearium das Irmandades da Fala, e pasou a ser o órgano oficial do Partido Galeguista (PG) durante os anos da República). Tivo efectivamente certo peso entre cantos alimentaban ese ideario nesa etapa tan decisiva como convulsa, pero sen conseguir saír nunca dese círculo social de elite. Esta limitación expansiva fíxoa constantemente debedora do voluntarismo de cantos sucesivamente

\footnotetext{
${ }^{1}$ Beramendi, J. (2002): «Prensa y galleguismo político, 1840-2000», en Almuína, C. / E. Sotillos, Del periódico a la Sociedad de la Información, Madrid, España Nuevo Milenio.
} 
ían tendo protagonismo ou influencia no movemento galeguista. De aí que tamén sufrira as consecuencias da escisión que obriga a Antón Villar Ponte a dimitir como director en 1922, responsabilidade que asumirá entón Víctor Casas. Que non estivese sustentado por unha organización política —as Irmandades nunca estiveron estruturadas como partido- e buscase só lectores dese círculo de intelectuais e ideólogos da pluma e da nación viable provocaron na vida desta publicación fortes oscilacións nas diferentes fases polas que pasou.

A escaseza de recursos económicos e de lectores, as diferenzas ideolóxicas no movemento que lle daba apoio así como as circunstancias políticas que convulsionaron a época e con ela o sistema comunicacional no que se proxectaba motivaron que $A$ Nosa Terra se vise obrigada a mudar de periodicidade en varias ocasións. Foi decenal ata febreiro de 1921, quincenal ata 1925 e mensual desde esa data ata que de ser prensa de tendencia pasa a ser prensa de partido, sometida durante todo ese tramo aos rigores da ditadura primorriverista.

A segunda das cabeceiras ás que me referín é a que se corresponde co diario Galicia (1922-26), un proxecto dirixido en Vigo por Valentín Paz-Andrade, de vital transcendencia no proceso modernizador da prensa — nos niveis de profesionalización, nos contidos e na utilización dos xéneros informativos- e, polo mesmo, no proceso modernizador do país. Aínda que de maneira experimental, porque a súa curta vida impediu que se asentase como tal, danse nesa cabeceira os elementos que identifican o modelo dunha prensa de masas. Todas esas características estruturais e profesionais diferénciano de $A$ Nosa Terra, que ata a súa etapa de refundación nos anos setenta nunca deixou de exercer exclusivamente como prensa ideolóxica.

O diario vigués non desmereceu en nada do que ofrecía a prensa de información xeral, autodenominada independente pero en realidade moi escorada e sometida a fidelidades de partido ou de institucións como a da Igrexa católica. Tampouco na comparativa entre as diferentes tiradas, pois que se sostivo nos doce mil exemplares, por enriba de El Ideal Gallego (10 000), El Noroeste (6200) ou Diario de Pontevedra (800), entre outros que contaban con cifras semellantes. 
A Nosa Terra, en cambio, acomodouse ao que é habitual en publicacións parecidas que non deron o salto entre as elites ás que se deben e o público heteroxéneo que alimenta a prensa de empresa, informativa e de masas. Nunca pasou por iso dos 2000 exemplares. Cousa ben distinta é se a comparanza entre a prensa que demos en chamar de tendencia galeguista e/ou nacionalista e a comercial ou mesmo a de tendencias varias a levamos a cabo en termos absolutos, porque a desproporción numérica é enorme.

Unha terceira cabeceira, Heraldo Gallego (Ourense, 1930-36), que pasaba por ser o portavoz oficioso da dereita galeguista, cuxos membros decidiran escindirse do PG que escoraba á esquerda por necesidade, non chegaría a ter influencia territorial, malia que algúns dos seus animadores, como Vicente Risco, formasen parte xa do equipo de intelectuais de máis sona no país.

\section{A DEBILIDADE ESTRUTURAL E PRESENCIAL DA PRENSA GALEGUISTA}

No deficitario estadio sociocomunicacional que veño describindo, dificilmente a prensa galega, en xeral, e a de tendencia galeguista, en particular, puideron exercer o poder de mediación e de propulsión que se permitiría e acadaría a prensa en sociedades máis avanzadas, no momento en que as elites máis concienciadas proxectan estratexias para encarar o proceso de transformación dunha identidade étnica ou cultural en identidade nacional. Unha mágoa, porque é nos momentos máis tensos e conflitivos dunha colectividade, como o é ese proceso, onde o papel dos medios adquire unha importancia decisiva, tal e como se constatou noutros escenarios en que a sociedade de cultura e comunicación de masas está moito máis desenvolvida.

Nin sequera durante os anos da II República, que tanta efervescencia política provocara, unha vez recuperada a liberdade de información e de prensa que a ditadura de Primo de Rivera mantivera rixidamente controlada. A prensa de 
empresa ou comercial e a de tendencia non galeguista ou nacionalista, con ou sen partido detrás, non fan do feito galego un obxectivo estratéxico como a esas alturas sucedía con ese mesmo tipo de prensa en Cataluña. Pola contra, a máis comercial amosa desafecto, e a de tendencia non esconde a súa hostilidade contra os actores políticos e sociais máis identificados coa idea de Galicia como centro estratéxico de referencia e afirmación política, e de entre eles a prensa na que se expresan e manifestan ese ideario. Xa viña de atrás, pero increméntase esa hostilidade nas polémicas que as hemerotecas gardan coma ouro en pano. Foron soadas por exemplo as que o diario católico El Ideal Gallego provocou continuamente con $A$ Nosa Terra, e non menos duras son as que lanzan con idéntico obxectivo os proliberais El Orzán e La Voz de Galicia, ou o conservador Faro de Vigo, neste caso con menor insistencia, talvez por mor da escasa forza que tiña o galeguismo nesa cidade do sur.

En xeral, a prensa de dereita e centro-dereita é visceral en contra das ideas e proxectos que reforzarían a identidade comunitaria de Galicia, e en contra das publicacións que as coproducen e difunden. Unha actitude que comparte, aínda que con menos carga de visceralismo, a prensa socialista, comunista e anarquista, que acusan o nacionalismo e a prensa que se fai eco del de burgués e mesmo de reaccionario. Nestes últimos casos ata que o Partido Galeguista entra na Fronte Popular en 1935, tolerándoo a partir dese momento e compartindo con el e cos medios galeguistas a defensa do Estatuto de autonomía.

Todo o contrario do que sucedía a esas alturas en Cataluña, onde a prensa no seu conxunto, e non só a "catalanista», converxeu na vontade identitaria que unha sociedade renovada e moderna, e unha sociedade civil moi activa, se encargaron de facer visible. Segundo os estudosos destes procesos, toda a prensa catalá se converteu canda a intelectualidade na punta de lanza que lle habería de dar presenza a unha ideoloxía nacionalitaria, que lle dá consistencia á identidade nacional de Cataluña. Coa lingua como un dos seus elementos básicos.

A proba da debilidade estrutural e presencial desa prensa galeguista e/ou nacionalista podemos calibrala no feito de os seus líderes ter que buscar publicacións 
doutras tendencias ideolóxicas nas que dar a coñecer as súas ideas e proxectos. Sobre todo despois da abrupta desaparición — vítima da ditadura primorriverista- do Galicia, no que confluíran todos. Chegan con esa orfandade á II República. Co Galicia pechado e con A Nosa Terra desactivada cara a fóra (daquela xa era o voceiro oficial do Partido Galeguista), os ideólogos e propagadores do galeguismo político e cultural, ou do nacionalismo, unicamente atoparon:

- boa receptividade no coruñés El Noroeste, que dirixía en 1933 Roberto Blanco Torres; - máis ben pouca no ourensán e agrarista $L a$ Zarpa, o xornal fundado e dirixido polo crego Basilio Álvarez, no que se advirte daquela e a respecto da súa primeira época (tendo como redactor a Blanco Torres) un retroceso na súa liña progresista e galeguista; - e inicialmente en El Pueblo Gallego (fundado en 1924). Digo inicialmente porque, se ben o seu propietario e director, o liberal republicano Manuel Portela Valladares, socorreu os líderes do galeguismo e do nacionalismo prestándolles espazo nas súas páxinas de opinión para a exposición das súas ideas e proxectos, entre eles o da defensa a prol do Estatuto de autonomía, do que ese xornal foi tamén un abandeirado, acabou cortando con eles desde o momento en que, por ambición política, acomodou a súa liña editorial ás estratexias político/partidarias do poder central, e mesmo chegou a ser nomeado en 1935 presidente do Consello de Ministros.

Nesa situación de indixencia comunicacional, nunca tan orfos de prensa e de comunicación co pobo estiveron os vellos galeguistas, agora nacionalistas; xusto cando todo o ideario que trasladaran a través de A Nosa Terra (a idea de territorio con esa dimensión total que se expresa no concepto de Terra, a fundamentación histórica ou a indisociabilidade da historia e da nación, a lingua como factor de comunicación pero tamén de identificación) estaba a punto de ter unha estruturación político/xurídica no Estatuto de autonomía. Ese fora o discurso co que os homes de ideas, a intelligentia galeguista, se esforzaron en suplir os déficits de conciencia identitaria que, por razóns socioculturais e políticas, amosou durante anos a sociedade galega no seu conxunto. 
Para valorarmos o significado desa orfandade, quero traer a colación o que os teóricos do nacionalismo — un deles, Deutsch — achegaron a respecto do que para a formación da nación (o tránsito desde a etnia cultural á nación) comportan non só determinadas precondicións políticas, senón tamén determinadas precondicións sociais, como a da comunicación. Os medios de comunicación estarán, así, entre os mecanismos sociais de produción, reprodución e cambio, contribuíndo de maneira decisiva e necesaria, e actualmente de maneira imprescindible, á conversión das identidades colectivas étnicas en identidades colectivas nacionais.

O citado Deutsch, entre outros, concédelles aos medios nese proceso de conversión da identidade colectiva étnica en identidade colectiva nacional igual causalidade que a que lle concede á mobilización social. Aducen, en consecuencia, que a modernización que comportan ambas as dúas causalidades avivará a conciencia cultural diferencial dos grupos intraestatais. Acabaremos concluíndo que aquelas realidades étnicas que contan cunha meirande densidade de redes de comunicación son as que resultan máis susceptibles de propiciaren ese tipo de procesos nacionalitarios.

E coinciden, ademais, eses teóricos en que as bases ideolóxicas que sustentan esa converxencia de estratexias e vontades compartidas a prol da nación viable han de estar configuradas pola intelligentia — sinteticémola nos homes e mulleres de ideas-, que será a que proxecte como doutrina policéntrica ${ }^{2}$ o tránsito da identidade prenacional á identidade nacional na súa dimensión social, política, cultural e institucional.

Intelligentsia e nacionalismo relaciónanse na medida en que aquela é o instrumento que fai posible a configuración, organización e distribución do contido nacionalista; a que fai posible a existencia dunha conciencia nacional, que uns e outros entenden como un conxunto de percepcións, sentimentos e aspiracións

${ }^{2}$ Kohn, H. (1949): Historia del nacionalismo, México, FCE, 27-28. 
compartidos por un grupo de persoas respecto da súa nación. A ideoloxía nacionalista xorde a partir da intelligentia e posteriormente é asumida e aceptada polo pobo $^{3}$.

Cando esa conciencia se dá na periferia, acaba manifestándose incompatible coa idea do Estado/nación, e en consecuencia tende a singularizarse e a esixir unha descentralización efectiva do poder, que non poderá ser meramente territorial, porque tamén se expresa con razóns políticas que lle afectan á propia lexitimidade do Estado. O feito nacional devén en cuestión nacional no ámbito da conciencia cando nun mesmo territorio dous ou máis nacionalismos — que son expresión dunha idea de nación e dun poder nacional— disputan o dereito a administrar a identidade colectiva.

Con éxito para un ou para o outro na medida en que a mobilización social, por unha parte, e a estratexia comunicacional, pola outra, conflúan a prol dun ou a prol do outro. Neste noso caso de Galicia, esas dúas grandes precondicións nunca foron o suficientemente consistentes e operativas como para inducir e provocar esa transición cara a un autogoberno de nación, que estivo sempre, con maior ou menor tensión segundo as épocas, no ideario dos movementos galeguistas, e da intelligentsia que lles veu dando alento e significado. Dígoo sen restarlles nin un chisco de valor ao heroísmo de cantos, como é o caso de Plácido Castro, participaron nesa cívica cruzada.

O golpe militar do 36 truncou o percorrido da prensa de ideario republicano, galeguista e autonomista. As publicacións destas tendencias levaron na súa práctica totalidade o mesmo camiño que os partidos políticos e os sindicatos obreiros, todos eles ilegalizados. El Pueblo Gallego é un dos diarios que o réxime franquista considera botín de guerra, polo que foi incautado e pasou a formar parte da Cadena de Prensa del Movimiento, controlada inicialmente polos

\footnotetext{
${ }^{3}$ Naím, T. (1979): Los nuevos nacionalismos en Europa, Península, Barcelona, 103-104.
} 
falanxistas ${ }^{4}$. A outra prensa —os diarios de empresa, que eran os que levaban a batuta en lectores e rendibilidade comercial— púxose do lado dos sublevados e someteuse sen reparos á xurisdición militar, primeiro, e á normativa de signo totalitario que impón a Lei de prensa de 1938, despois.

A lexislación atribuíalle ao Estado a organización, vixilancia e control de toda a prensa, e en concreto: regular o número e extensión das publicacións periódicas - o que provocou a caída inmediata das non adscritas ao bando dos vencedores—, intervir na designación do persoal directivo dos periódicos, regulamentar a profesión periodística creando un rexistro oficial no que os xornalistas estaban obrigados a inscribirse así como controlar os contidos informativos e de opinión, aplicándolles a censura e o aparato sancionador, que ía desde a multa á incautación, pasando pola destitución do director.

Nos anos 50 e 60, o galeguismo cultural e o nacionalismo político tentaron acceder a outras palestras mediáticas — minoritarias, de elite- para saíren da forzosa clandestinidade política e intelectual. Tiñan dificultades na prensa convencional. Porque estaba moi lonxe das súas ideas e angueiras, e porque debían coidarse de publicar informacións ou artigos que non cadrasen co san rexionalismo, o que na práctica supuña someter a corentena informativa feitos e manifestacións locais que fosen susceptibles de ser interpretados en clave galega, o que de feito colocaba a lingua na marxinalidade.

Subliñarei catro destas publicacións alternativas nas que os galeguistas de sempre e os novos nacionalistas verteron as súas ideas en artigos e ensaios, nalgúns casos mesmo provocaron problemas coa censura. Por unha banda, a Revista de Economía de Galicia e Grial (literatura e pensamento, acollendo esta última a tradución ao galego que Plácido Castro fixo das Rubáiyát, a obra de Omar

\footnotetext{
${ }^{4}$ A Lei de prensa e imprenta de 1966 (ou Lei Fraga) non modificou o status das 39 cabeceiras que integraban a Cadena. En 1977, xa na Transición, pasaron a integrarse no organismo autónomo Medios de Comunicación Social del Estado. Dous anos despois, El Pueblo Gallego pechou por non rendible. O Goberno socialista vendeulles as cabeceiras que aínda quedaban a empresarios do sector.
} 
Kháyyám, e, no mesmo ano da súa morte, un ensaio sobre W. B. Yeats), ambas as dúas creadas, e non sen dificultades, pola editorial Galaxia pouco despois da súa fundación (1950). Pola outra, as revistas Galicia Emigrante e Vieiros, que dirixían en Bos Aires e México, respectivamente, os intelectuais exiliados Luís Seoane e Carlos Velo/Delgado Gurriarán/Luís Soto. No interior tamén puideron acceder ao xornal compostelán $L a$ Noche na tempada en que o dirixía Raimundo García Domínguez (Borobó). A chamada Lei Fraga (1966), da que tanto se xactaba o exministro de Franco e futuro presidente do Goberno autonómico de Galicia (paradoxos dunha transición pactada), aparentaba o que o seu artigo 2 mataba a traizón (multas, secuestros, peches forzados...).

\section{PLÁCIDO CASTRO: O DISCURSO XORNALÍSTICO}

Plácido Castro pertence a esa xeración de intelectuais e políticos galegos que conciben e fan uso da prensa como un dos principais activos para a creación de conciencia cidadá. Decatáranse de que a prensa é un actor social imprescindible para asentar en Galicia aquelas alternativas ideolóxico/políticas que confluían, non sen tensións, na Europa de entreguerras. Coincide, ademais, cos anos en que os xornais afrontan unha fonda e transcendental reconversión industrial e, conseguintemente, profesional das súas estruturas, urxidos sen dúbida polos cambios sociais e culturais que van experimentando os públicos; consolídase, así, a prensa de masas.

Séntense apurados pola sucesión de acontecementos e, auxiliándose dos novos mecanismos de transmisión, fan da prensa un obxectivo prioritario. Desbotada a prensa de empresa, que lles era adversa, tentaron establecer lazos en cabeceiras de vocación política, como El Orzán, La Zarpa, Galicia, El Pueblo Gallego ou El Pais, e, por suposto, na prensa de ideario, que foi por exemplo $A$ Nosa Terra, que alimenta o modelo de xornalismo ideolóxico co que arrancara o século XX. Ocupan esas e outras cabeceiras de menor entidade posicións nas que 
se autoafirman sucesivamente en Galicia o agrarismo (por caso, La Zarpa), o nacionalismo (como Galicia) e o republicanismo (por exemplo, El Pueblo Gallego ou El País).

Esa xeración conquista os espazos xornalísticos, ora desde dentro das redaccións (un Blanco Torres ou un Xohán Carballeira, entre outros), ora desde a condición de colaboradores, como é o caso de Plácido Castro desde que en 1927 decide participar nesa estratexia de propulsión cívica. Os índices de urbanización e alfabetización seguían sendo moi baixos, pero avanzaban, o que lle daba azos aos que, coma el, estimaban que sobre eses vimbios era posible afianzar un proxecto político, liberal e progresista no país. Para o que era preciso, antes de nada, tomar conciencia desa realidade en construción. Cara a dentro e cara a fóra.

Os galeguistas do primeiro nacionalismo galego que xorde arredor das Irmandades da Fala, nomeadamente un dos seus apoios máis sólidos, Antón Villar Ponte, atoparon en Plácido Castro un lúcido e culto propagador de ideas e un razoablemente ácido fustrigador do centralismo desnaturalizador, pero tamén quen posuía a visión máis aguda sobre a necesidade que tiña de lexitimarse, e con el Galicia, no ámbito xeopolítico europeo e, andando o tempo, a ambas as bandas do Atlántico. Estaba entre os mellores embaixadores para esa dobre función, tal como se pode comprobar tanto nas que el mesmo denomina crónicas coma nos artigos ensaísticos que iría publicando en El Pueblo Gallego e puntualmente no Informaciones de Madrid, así como nas publicacións do PG $A$ Nosa Terra e Ser, primeiramente desde Gran Bretaña, país onde viviu os seus anos de formación básica e universitaria, e despois en Galicia, á que volveu en 1930 e na que permaneceu entregado na acción política do galeguismo ata o levantamento golpista do 36.

Sábese que forma parte da intelligentia que no seu país, na nación que no ano 1933 e grazas ao seu traballo de mediación no nome do PG foi recoñecida como tal no IX Congreso de Nacionalidades Europeas realizado en Berna, tenta facer realidade o proceso de conversión da identidade colectiva étnica en identidade colectiva nacional, e introduce no discurso do nacionalismo, con sorprendente 
orixinalidade, unha argumentación de espello cóncavo (comparativa, coa imaxe de Irlanda, sempre presente). Irlanda e Gran Bretaña ofrecen para el o mellor modelo para comprender que un país pequeno con identidade pode singularizarse no mundo, enriquecendo así o patrimonio común universal. E artella ese pensamento sobre dous elementos esenciais e inseparables, aos que tamén fará mención Castelao: a saudade e o celtismo (forza cultural que, segundo subscribiu Plácido, lle ha servir de complemento ao nacionalismo), do que deduce ademais a necesidade de que Galicia conte cunha ben deseñada política exterior (que el mesmo acabaría concretando para o PG, sen posibilidades de poñela en práctica, nas vésperas da Guerra Civil: fraternidade ibérica con vascos e catalás, intensificación das relacións cos pobos e cultura portuguesa de ambos os dous lados do Atlántico, estreitamento dos lazos que nos unen ás terras célticas de Europa, segundo Xulio Ríos). Velaí polo que ten no nacionalismo irlandés (o daquela época, naturalmente), e non no nacionalismo catalán, o modelo de referencia para o nacionalismo galego.

Foi este un fío discursivo co que desenvolve — por capítulos/artigos e non en libro ensaístico - as liñas fundamentais do seu pensamento político. Faino antes da súa condena e inhabilitación en El Pueblo Gallego e A Nosa Terra, e verase obrigado a buscar outros soportes xornalísticos fóra, cando xa asentou o franquismo e decide exiliarse en 1949, primeiramente en Estoril (Portugal) e posteriormente en Londres. Velaí os artigos publicados no portugués O Jornal de Notícias (Porto), no que consegue manter a sección "Aquí Londres», aproveitando a mediación dos contactos que conseguira durante a súa estadía en Portugal; no bonaerense El Correo de Galicia e na revista da diáspora Céltiga, así como en La Nación (o diario arxentino dos Mitre, no que colaboraba Eduardo Blanco-Amor) (o mediador?). É neste xornal bonaerense onde expresa de maneira máis directa a súa "Justificación del nacionalismo»: «Galicia es más que una división geográfica y tiene elementos materiales y sentimentales para ser una nación. El sentimiento patriótico es más patente y perdurable que las razones materiales y económicas». 
Iso si, sen romper en ningún momento co seu reivindicado liberalismo ideolóxico. Nunca asumirá como desencadeante da singularidade nacional de Galicia a súa independencia ou secesión. En troques, si que defenderá o sentido da independencia de cada individuo, e niso sitúa o fundamento do liberalismo. Máis aínda, como pon de manifesto nun artigo de A Nosa Terra, en 1931, identifica o ser galego con ser liberal: «E asi opinamos que o espíritu galego foi sempre tan fondamente liberal, que incluso por tradicionalismo ten que ser liberal o galeguismo». Non temos noticia de como o sector máis esquerdista do galeguismo, e máis en concreto falando de prensa e xornalistas desa tendencia, un Blanco Torres, recibirían ese discurso. A única polémica interna que se coñece é a que mantivo Plácido Castro con Johan Carballeira a propósito da lingua galega, e do cosmopolitismo que o xornalista asumía como inevitable, o que puña en risco a singularidade do idioma de Galicia.

Durante os anos 40 seguiu mantendo Plácido Castro desde Londres o seu discurso xornalístico co ton político/divulgativo dos seus primeiros anos como colaborador/articulista/cronista. Fará un seguimento moi exhaustivo da evolución política de Gran Bretaña, e especialmente da confrontación entre laboristas e conservadores. Recollo de João Conde Veiga as características que descobre na análise das prosas, ou crónicas, que publica en O Jornal de Notícias entre 1949 e 1950 e nas que achega o seu punto de vista sobre a vida inglesa: profunda admiración pola democracia, rexeitamento dos extremismos que poden ser admitidos nunha democracia, entusiasmo polos resultados da práctica democrática en contraste coas noticias que lle chegan desde España e Galicia, a secreta esperanza de que os resultados democráticos observados en Gran Bretaña poidan ser unha realidade na España que recoñeza a diversidade ou singularidade de Galicia, unha clara intención de provocar o debate (social, político, cultural) entre os seus lectores.

Esas crónicas interpretativas daranlle a oportunidade de volver sobre algunhas das súas ben testemuñadas referencias ideolóxicas, sempre tinguidas de humanismo. Por exemplo, contra a pena de morte. Ou o camiño utópico dunha socie- 
dade sen clases. Ou a condena expresa da politización da ciencia. Ou o tema da unidade, tendo como referente o modelo posbélico representado pola Commonwealth. Aproveitaba as alocucións do programa da BBC no que traballou durante seis anos como redactor e como locutor —o primeiro programa radiofónico en galego e no exterior, acordado nunha reunión realizada en Vigo (anos 50) co director da emisora, Mr. Hills, na que participaron Del Riego, Paz-Andrade, Carlos Maside, os irmáns Álvarez Blázquez e o propio Plácido Castro- para que, unha vez traducidos do galego ao portugués, se publicasen no diario de Porto, en La Nación e en Galicia Emigrante.

A volta definitiva a Galicia. Cando lle levantan a inhabilitación, regresa e vive aquí, en Cambados. Traballa no Instituto Laboral de Vilagarcía, onde exerce como profesor de inglés. E colabora de novo, pero xa noutro ton e con temas máis culturais, sociais e costumistas, no Diario de Pontevedra, no incautado El Pueblo Gallego e, sobre todo, no Faro de Vigo (a primeira cabeceira de empresa, prensa comercial, que lle deu unha oportunidade, seguramente da man de Cunqueiro, o director, que mantiña nel a súa célebre sección diaria, «El Envés», coa que ás veces interaccionaba Plácido Castro para argallar os seus textos, agora si, máis literarios e culturais, mesmo costumistas). Todo o demais era clandestino. 


\section{PLÁCIDO CASTRO \\ E $O$ UNIVERSALISMO}

Rubén C. Lois González

Universidade de Santiago de Compostela

DOI: $10.17075 /$ vipc.2020.005 



\section{A MIÑA DESCUBERTA DE PLÁCIDO CASTRO}

Como xa manifestei nalgúns escritos previos, a traxectoria da xeografía española e galega en análises de xeografía política ou xeopolítica foi moi cativa e localizada. A súa cativeza deriva aínda da pesada lousa do franquismo nas institucións universitarias do país, en particular nas ciencias sociais, onde hai temas máis e menos apropiados para tratar na investigacións, e a xeopolítica entrou na categoría dos segundos até hai poucos anos. Logo, respecto ás persoas que si abordaron estas cuestións, cómpre destacar unha serie de autores moi localizados no espazo catalán e valenciano ou formados na Facultade de Ciencias Políticas de Madrid (López Trigal / Benito del Río 1999, Nogué Font / Vicente Rufí 2000, Romero 2004). Toda esta argumentación serve de propósito para xustificar o meu descoñecemento durante moitos anos da traxectoria e o legado vital de Plácido Castro, e a enorme orixinalidade e proxección actual das súas propostas.

De feito, de non mediar o labor continuo do Instituto Galego de Análise e Documentación Internacional (IGADI) na difusión da súa obra e de non existir un centro que leva o seu nome en Cambados, seguramente o esquecemento inxusto de Plácido Castro se mantería algún tempo máis. Por todo isto, quero expresar un primeiro recoñecemento ao persistente labor de Xulio Ríos en recuperar o legado deste galego universal (Ríos 2002 e 2004, Trillo / Lois 2016). Cando se descobre a Plácido, as identificacións coas súas propostas e testemuño vital agroman; en particular, sempre chama a atención como un galego de comezos e mediados do século XX se abriu ao mundo, comprendeu a esencia das nacións célticas ou atlánticas, nun país onde ficar pechado na leira resulta un comportamento máis frecuente do que sería desexable. Por iso, cómpre aplaudir e defender activamente o traballo da Fundación Plácido Castro e todo o que nos 
achegou o IGADI nestes decenios coa súa ollada. Unhas olladas sen complexos e desde o compromiso co país, sobre un mundo globalizado, interconectado, onde a curiosidade respecto ao que hai máis alá dos nosos límites é unha das poucas ferramentas que nos permitirá ser cidadáns activos no mundo do presente.

Foi co IGADI e coa Fundación como eu me acheguei superficialmente e nun primeiro momento a Plácido Castro. Pero a miña experiencia inicial recorrendo a el non podía ser máis clarificadora. No 2007 visitamos Irlanda, o condado de Kerry para reforzar os vínculos Galicia-Irlanda na música e na cultura, e Dublín para apoiar a presenza de Air Lingus no aeroporto de Santiago de Compostela, da man dun incremento dos fluxos turísticos e das peregrinacións cara á nosa terra. Eu participaba nun goberno da Xunta de Galicia diferente e consideramos que era mellor dirixirnos aos operadores turísticos irlandeses apelando ao corazón e aos vínculos afectivos célticos, atlánticos ou fisterráns, como queiramos chamalo. Levamos un excelente gaiteiro, albariño e bos cociñeiros do Centro Superior de Hostalería de Galicia, e falaron dous membros do Centro de Estudos Irlandeses da Universidade da Coruña, Antonio de Toro e David Clarke. Eles remitíronnos a un mundo común de lendas, que comeza apelando a deuses como Breogán, que segue con San Patricio e as peregrinacións a Santiago, con Alfredo Brañas e a súa ollada a Irlanda, logo continuada por Castelao e outros ao longo do século XX. E que remata con datos tan importantes como que a primeira tradución de J. Joyce a unha lingua peninsular foi ao galego e que os escritos de Plácido Castro informaron puntualmente das paisaxes das illas Arran (como a nosa Costa da Morte), da revolución irlandesa de 1916 e dos seus acontecementos ulteriores nos debates do parlamento de Dublín, como novas para o noso país irmán do sur (Castro 2016).

Nese acto, o embaixador español presente indignouse, viu un fondo ataque á «unidade nacional» que os galegos exercésemos e reivindicásemos a paradiplomacia, ensinada por Plácido Castro. Marchou cedo e nós quedamos coas felicitacións de moitos operadores turísticos irlandeses, que asistiran a unha presentación distinta, emotiva para eles. Fora fundamental o legado e as alusións tanto á 
cultura como ao labor de ponte que fixera Plácido Castro. Santiago de Compostela non ficaba como unha pequena cidade do norte de España e fin dun Camiño histórico, senón tamén como urbe simbólica e capital dun país con enormes afinidades e aprendizaxes históricas da República de Irlanda. Air Lingus segue operando con avións cheos de Dublín a Compostela boa parte do ano, porque aparecemos no mapa.

Logo, nesa e noutras viaxes a Irlanda (tamén a Gales e Escocia) gústanos pensar que camiñamos guiados polos escritos de Plácido. Os debates entre autonomistas e independentistas no Parlamento de Dublín, a reivindicación do premier de orixe galesa Lloyd George, as similitudes na mestura dos verdes do campo co azul do océano en todos os nosos países e a forma céltica, ou atlántica, de contemplar o mundo. Pasear por Dublín e polas áreas rurais do oeste de Irlanda mellora lembrando as miradas previas de Plácido Castro, escoitando as gaitas ou os poemas lidos en diferentes linguas e entendendo, en definitiva, que os territorios atlánticos das fisterras europeas teñen unha irmandade innegable.

\section{PLÁCIDO CASTRO E A XEOPOLÍTICA}

Como evocabamos agora, o centro do mundo de Plácido Castro son as nacións célticas, en particular as localizadas nas Illas Británicas e Galicia. Irlanda como modelo, Gales por posuír un tamaño similar ao do noso país e tamén a cidade de Londres como altofalante das afinidades, a través da serie de programas radiofónicos que transmitiu desde a BBC. Os celtas sentimos dun xeito semellante, defendemos o noso, somos tolerantes coas culturas veciñas e mantemos unha cosmovisión con enormes puntos de coincidencia, onde a natureza, a paisaxe así como e a tradición oral e literaria nos dotan de sentido moi arraigado de comunidade.

Neste senso, sempre nos interesa lembrar ao historiador catalán J. Vicens Vives, que, ao referirse á Península Ibérica, escribía que esta se podía explicar a 
partir de alongamentos lonxitudinais de reinos durante a Idade Media e que os territorios non só se definían por si mesmos, a partir duns límites nítidos con outras realidades veciñas, senón mediante transicións e interseccións (Vicens Vives 1970). De feito, Cataluña continuouse ao longo da Reconquista polo Reino de Valencia e o de Mallorca, cos que segue a manter indubidables afinidades culturais, Asturias por León, logo Castela e finalmente a nova Castela que será Andalucía. Sen dúbida, desde Galicia conformouse o Reino de Portugal, que logo sería fundamental na era das descubertas saíndo de Europa a través das súas colonias americanas, asiáticas e africanas. Os territorios en si, pero estendéndose e creando tránsitos cara a outros cos que seguen vinculados. Partindo de que a asociación de Galicia con Portugal resulta incuestionable, tamén o mantemento de semellanzas cos países ou nacións célticas ou atlánticas de Escocia á Península Ibérica, pasando por Gales, Irlanda, Cornualles e Bretaña, pode ser outra forma de definir a identidade galega (Lois 2015).

Se procuramos máis asociacións entre as nacións célticas, un tema tan querido por Plácido Castro, os exemplos son múltiples desde a xeografía e outras ciencias sociais. De feito, todos estes territorios mantiveron contactos marítimos desde a Protohistoria, como mostra a existencia de relatos sobre as Casitérides, recollidos logo por Heródoto e Estrabón nas súas crónicas (Bermejo 1982). O contacto debeu manterse ao longo da Idade Media, cunha intensificación continua até uns intercambios moi frecuentes no eido comercial e das peregrinacións desde o século XIII. De feito, os fluxos mercantís na periferia atlántica europea foron unha constante ao longo da historia. Pero quizais o máis interesante son as enormes similitudes que as sociedades labregas atlánticas mantiveron en todas as épocas do pasado, cos dramáticos procesos de superpoboación rural nos séculos XVIII e XIX, que conduciron a centos de miles de galegos, irlandeses, portugueses ou escoceses a emigrar cara a América, ben fose á do Norte, ben cara a Arxentina, Cuba ou Brasil, entre outros, segundo se organizaban as redes migratorias e as afinidades culturais (Lois 2002). Mesmo a introdución da pataca como produto que solucionou moitos problemas alimenticios nos asemella; tamén un 
xeito intensivo de traballar a terra, que permitiu construír paisaxes próximas, e unha cultura material (con elementos etnográficos) de enormes parecidos. Unicamente a vocación mariñeira foi máis intensa en Galicia e Portugal, pero os nosos pescadores cedo coñeceron as riquezas do mar céltico, desde o Grand Sole até o Box irlandés e as illas Orcadas, onde pescar abundantes recursos.

Só faltaba un último elemento, que todo o que nos uniu e os une fose codificado pola cultura contemporánea mediante dinámicas de (re)invención da tradición (Anderson 1983). Deste xeito, se en Irlanda, Escocia, Bretaña e Galicia se tocaban as gaitas, agora co pulo da música celta fanse composicións, pezas e creacións musicais moi parellas e, sobre todo, relacionadas. Tamén, e chega con evocar a E. Pondal para situármonos en contexto, a literatura fixo e fai continuos sinais de irmandade. Álvaro Cunqueiro podería migrar como autor ao norte, e logo numerosos escritores máis afirman continuamente a identidade atlántica a través dos seus textos líricos ou en prosa. Existe unha comunidade evidente, que non segue as conexións terrestres senón as rutas marítimas e as afinidades culturais, que Plácido Castro foi un dos primeiros en ollar, describir e reivindicar.

\section{A XEOPOLÍTICA, A PARADIPLOMACIA E A CONSTRUCIÓN DUNHA NACIÓN}

Nos debates teóricos en xeografía e outras ciencias sociais, a definición de xeografía política, as súas semellanzas e diferenzas coa xeopolítica son obxecto de atención (Taylor 1994, López Trigal / Benito del Río 1999, Nogué Font / Vicente Rufí 2000). Así, a xeografía política procura analizar as relacións das organizacións políticas e as institucións de goberno cos territorios onde se integran, nun primeiro momento outorgándolle moito protagonismo ao Estado-nación e, máis recentemente, considerando o papel condicionante da escala global, e os procesos locais e comunitarios na construción de estruturas de poder e actores públicos. Pola súa banda, a xeopolítica presentouse como a versión 
aplicada da xeografía política, primeiro considerando aos Estados como organismos (seguindo as teorías de Ch. Darwin), que necesitan loitar por sobrevivir e expandirse se os recursos naturais do seu territorio non chegan, agora como un derivado das estratexias de dominación das grandes potencias, os efectos das políticas públicas das organizacións e tratados supranacionais, os xogos de alianzas na escena internacional, e as afinidades civilizatorias, relixiosas, lingüísticas e culturais de determinadas partes do mundo e as consecuencias derivadas destas (Taylor 1994, Kaplan 2013).

En numerosos documentos, moitos impulsados e difundidos desde o IGADI e outras fundacións galegas, apuntouse o concepto de paradiplomacia (Criekmans 2010, Bargallò / Castellà / Marí 2013, Grydehoj et al. 2014). Esta consiste nas accións concretas de relacións internacionais que desenvolven institucións non dependentes do Estadonación central. Así, os gobernos vasco e catalán animaron accións de paradiplomacia cando instalan embaixadas e delegacións de diverso tipo no estranxeiro, pensadas para defender os propios intereses e establecer alianzas. No goberno de M. Fraga, Galicia desenvolveu unha axenda autónoma nas relacións con Portugal ou Cuba, por citar dous exemplos. As asociacións de escritores ou intelectuais de linguas minorizadas son outro caso de paradiplomacia, así como determinados encontros deportivos, actos e eventos de solidariedade internacional fronte a un conflito ou as declaracións públicas de concellos, asociacións ou persoas individuais para denunciar unha inxustiza.

A partir destes conceptos de xeopolítica e paradiplomacia, Plácido Castro elaborou unha interpretación e modelo de acción para Galicia. Non se sabe que coñecese os tratados académicos de xeografía ou de relacións internacionais, pero a súa ampla cultura e formación si lle permitían achegarse, aínda que fose intuitivamente, a estas nocións académicas. Deste xeito, e así o subliñamos (Trillo / Lois 2016), Plácido elixe o exemplo británico de nación para Galicia e o Estado español. O Reino Unido da Gran Bretaña é o resultado dun pacto político dos ingleses, primeiro cos galeses, aos que someten, logo cos escoceses, e nos inicios do século XX, con múltiples debates e sen consenso total, cos 
irlandeses. Polo tanto, a asunción de que nos topamos diante dun Estado plurinacional desde a súa constitución a ninguén sorprende. Gales, Escocia e Irlanda, con diferente status, nivel de autogoberno e institucións simbólicas ao longo da historia son realidades nacionais asumidas por todos os británicos. Do mesmo xeito, Galicia é unha indiscutible nación no contexto español e ibérico, enlazándose así co ideario e as practicas do galeguismo anterior á Guerra Civil que fixo escoitar a voz do noso país na Sociedade das Nacións e se articulou no Partido Galeguista. Na terrible posguerra esta consideración continuou expresándose desde Londres, e coincidindo coas elaboracións políticas máis conscientes deste período (Castelao 1944).

Cando se fala de senso británico de nación en Plácido Castro, e como apuntamos, xorden dous referentes primordiais que serven de modelo a Galicia: Irlanda e Gales. A loita de Irlanda pola súa independencia, os seus problemas territoriais e políticos internos, como realidade sempre mitificada polo nacionalismo galego e, por suposto, o vasco. Plácido coñeceu moi ben Irlanda e continuamente nos informou da súa dinámica política, da súa realidade territorial e da súa cultura, nun traballo que a partir de moitos escritos breves se volve fundamental. Pero Plácido Castro tamén gustou das afinidades que Gales expresaba con Galicia. Dous países dun tamaño e unha poboación similares, integrados nos poderosos reinos de Inglaterra e Castela a finais do século XV, cun fondo sentimento propio, que non obstante se manifesta dun xeito débil e moitas veces mediado no eido político. Para o autor os premiers galeses constituían un espello do que destacados políticos galegos podían ter feito, e non fixeron, nos gobernos de Madrid.

\section{COMO DEFINIR A GALICIA TERRA ENTRE...}

A interpretación de J. Vicens Vives a propósito de que os territorios non só se definen en si, senón como tránsito entre territorios e prolongación cara a outros, non se podería entender se desde hai douscentos anos non se instalara 
a denominada razón cartográfica (Farinelli 2009). Esta é o resultado da difusión da cartografía, da xeneralización do uso de mapas na sociedade e no ámbito escolar e, en consecuencia, o xurdimento dunha forma de razoar territorialmente a partir do seu emprego. De feito, Galicia e Portugal posúen moitos atributos culturais, paisaxísticos e históricos en común, pero se ollamos directamente un mapa do oeste da Península Ibérica todo se aclara moito mellor. Da mesma forma, as afinidades e semellanzas entre as nacións célticas ou fisterrás tamén se comproban observando un mapa do Atlántico europeo. Sen dúbida, P. Castro mirou e consultou os mapas para ratificar as súas lecturas e os seus ensaios. Cun bo mapa, Irlanda, Cornualles e Bretaña posúen unha continuidade con Galicia e unha parte do norte do Estado español, algo que sen cartografía sería moi difícil de conceptualizar.

Se avanzamos un pouco máis no noso razoamento, podemos concluír que a forma en que leamos os mapas non é neutra, indiferente. Sen dúbida, en Europa e en España proliferaron as interpretacións continentais e centrípetas. Segundo estas, semella que o centro da UE debe situarse entre Alemaña e Francia, incluíndo parte do Benelux, Inglaterra e o Norte de Italia; isto é, o que se chamou a banana azul, a partir da cal se definirían diferentes periferias e diagonais, como a denominada arco atlántico, onde se sitúan os países e territorios do confín occidental e atlántico do continente (Comisión Europea 1994, Cabero / Plaza 1997): Como xa apuntamos, normalmente a xeografía de España explícase desde Madrid e a Meseta central, o que supón un achegamento radial ao territorio español (Bel 2010) e a progresiva definición de periferias. Tanto ten que as periferias sexan ricas como Euskadi e Cataluña, insulares como Canarias ou Baleares, derivadas do mito da Reconquista como Andalucía, todas se ollan desde supostos centros. No seu conxunto teñen atributos diferenciais respecto á lingua ou a cultura dominante, todas son estacións termo ou fins de viaxe de vías de alta capacidade. A cartografía e os discursos continentais contrapoñen os nodos e os bordos, nunha lectura sempre interesada e discriminatoria de realidades socio-territoriais moito máis complexas. 
Como xa se indicou, se seguimos a J. Vicens Vives e a súa lectura xeográfica mediante continuidades, interseccións e franxas, a nosa visión varía. No ámbito europeo, os límites extremos tamén poden ser moi relevantes como Liverpool (sen dúbida, fito da modernidade cultural), Istambul (a cidade máis poboada de Europa) ou Sicilia, Creta e Chipre como berce das civilizacións da antigüidade. Do mesmo xeito, o mundo catalán, o xenovés ou o veneciano estendéronse polo Mediterráneo desde a Idade Media. Entre Galicia e Portugal existe unha evidente continuidade cultural, lingüística, paisaxística e histórica, un atributo que se pode comprobar entre o noso país e outras fisterras atlánticas, como P. Castro soubo moi cedo ver. E viuno desde as Illas Británicas, punto de observación privilexiado do marítimo e do inicio da globalización, territorio demasiado dependente de Londres, pero cunha Irlanda, Escocia, Gales, Man, Cornualles e o Norte de Inglaterra bastante autónomos.

$\mathrm{Na}$ actualidade, aínda que dun xeito leve, a rede de nacións atlánticas e célticas continúa no simbólico e a través de diferentes eventos. Desde un actor menor no noso relato, en Bretaña mantense a organización do máis importante Festival Intercéltico de Música en Lorient. Nesa cidade costeira reúnense durante unha semana de agosto músicos de Escocia, Irlanda, a Illa de Man, Gales, Cornualles, Asturias, Norte de Portugal e Galicia, xunto cos das colectividades bretoas de América do Norte. A música é desbordada por outros eventos culturais e por un sentimento común de irmandade entre os pequenos países atlánticos. Bretaña sempre reivindica a súa posición central entre as Illas Británicas e o Norte Ibérico, como nos lembraron diversos estudos académicos sobre a cuestión. Desde as Illas Británicas, a irmandade Escocia-Cataluña é un feito como a Irlanda-Euskadi no eido político. Reforzado polo papel simbólico do Camiño de Santiago coñécese o feito diferencial de Galicia; sen dúbida, a música, a paisaxe e as afinidades literarias unen moito. Por último, neste percorrido pola franxa de nacións atlánticas europeas cómpre dicir que a admiración de Plácido Castro polo irlandés, gales ou escocés se mantén, así como polo éxito dos exemplos de desenvolvemento económico recente da República de Irlanda e Bretaña. 


\section{O CELTISMO, O ATLANTISMO E AS FISTERRAS EUROPEAS}

Como apuntabamos nun comezo, as afinidades obxectivas entre os territorios atlánticos europeos foron puladas mediante relatos míticos de pasados comúns, que no noso ámbito reciben o nome de celtismo. Este movemento cultural e histórico enmárcase no definido como «invención da tradición», ao que se referiu B. Anderson no seu libro (Anderson 1983). O celtismo xorde da necesidade de dispor dunha historia propia como fundamento da idea de nación. No século XIX, os pobos sen historia non tiñan dereito a ser considerados realidades nacionais e, así, B. Vicetto e M. Murguía construíron a historia de Galicia como país celta, emparentado cos seus irmáns das Illas Británicas e do Finisterre francés. Logo, escritores xa citados como E. Pondal achegaron forza literaria ao mito e políticos como A. Brañas non renunciaron a el. Desde o punto de vista historiográfico, resulta difícil afirmar que é celta, se ben as linguas orixinais de Irlanda, Gales, Escocia e Bretaña, non latinizadas, se identifican con este cualificativo. Tamén a música a base de gaitas e outros instrumentos tradicionais se caracteriza así. Despois de moitos decenios de crítica dos nosos historiadores e arqueólogos ao mito do celtismo, hoxe en día ninguén nega afinidades históricas e culturais entre as sociedades atlánticas das fisterras europeas, e estas poderían entenderse en clave céltica como Pondal, Castelao, Cunqueiro ou P. Castro fixeron en diferentes períodos.

Para sustentar estas semellanzas no pasado de máis lonxe sempre se recorreu a un feito histórico evidente: a cultura do ferro chegou da man de pobos que procedían de Centroeuropa nos diferentes territorios en cronoloxías e mediante procesos semellantes. En boa medida a riqueza mineira destas terras (de Galicia ás Illas Británicas) xa animara unha rica cultura do bronce previa e culminará no mundo defensivo, castrexo para nós, dos séculos inmediatamente anteriores á romanización (Romero 1976, Méndez 1993). Estas evidentes afinidades, xunto cun medio natural bastante común, tamén explican que os gravados en pedra, as súas formas, sexan parellos. Cabe deducir que dun xeito máis ou menos con- 
tinuo houbo contactos e transferencias culturais e de innovacións ao longo do Atlántico europeo. E se esas vinculacións son máis incertas, como no remoto pasado megalítico con dolmens e pedras fitas en todos estes países, polo menos unhas condicións materiais do terreo e paisaxes próximas axudan a enmarcar testemuños patrimoniais non moi diferentes.

Como xa indicamos, durante toda a historia houbo contactos marítimos máis ou menos regulares entre as nacións célticas. Aínda que non existen moitos relatos nin documentos dos primeiros séculos da Idade Media (si mitos), resulta evidente que desde o século XII os intercambios comerciais e de persoas entre Irlanda, Inglaterra e Bretaña se foron intensificando. Deste proceso dá boa conta a popularización do Camiño de Santiago e as súas rutas marítimas, con saídas desde Cork, Dingel (condado de Kerry) ou Portsmouth cara a Galicia. Nun plano máis material, e moitos barcos que traían peregrinos eran estritamente mercantís, Galicia exportou viño ao longo da Idade Media cara ás rexións do Norte polo Atlántico e importou madeira (tamén sal); o comercio de sal e de tecidos podía posuír unha dupla dirección, ás veces importábase e outras exportábase. Pequenas cidades portuarias como Ribadeo, Viveiro, Betanzos, A Coruña, Noia, Pontevedra ou Baiona, entre outras, foron protagonistas destes intercambios e trazaron redes comerciais ao longo da periferia atlántica europea (Huetz de Lemps 1967, Portela / Pallares 1981).

Este significado de periferias irmandadas e de periferias internas nos respectivos Estados-nación actuais non foi asumido nin por Plácido Castro nin debe ser aceptado por nós agora. A noción de centro é simbólica e case sempre continental, o que non debe convencernos en Galicia. O noso territorio e a nosa sociedade, cun bo dominio das artes da navegación e do comercio desde hai séculos, deben afirmar o legado atlántico que xa se apuntou desde a xeración Nós e os galeguistas de comezos do século XX. De feito, nas rutas internacionais dos grandes buques mercantes actuais, as fisterras atlánticas europeas son lugares de tránsito ente África, América e Europa, e posúen unha localización central nos intercambios do comercio internacional. Cómpre manter esta lectura, 
reivindicar o desenvolvemento de eixes de conexión permanente entre Galicia, Bretaña e Irlanda cando menos (e o microcabotaxe marítimo pode ser unha opción) e construír unha nova xeografía céltica ou dos territorios fisterrás europeos, como xa afirmara Plácido Castro hai máis de medio século.

\section{A XEITO DE RECAPITULACIÓN}

O presente texto volve sobre a importancia, agora xeográfica e xeopolítica, dun pensador excepcional pola súa orixinalidade, Plácido Castro. Orixinal por dous motivos principais. A súa visión transnacional da realidade: Plácido contempla a Galicia desde dentro e desde fóra, pero é un dos primeiros en facelo como intelectual, non como emigrante económico, igual que lle acontecera desgraciadamente a miles de compatriotas. Ademais, Plácido lémbranos a raíz atlántica, fisterrá e céltica do noso país. As indubidables semellanzas e vinculacións que nos uniron e unen ao mundo británico, comezando por Irlanda, Gales e Escocia. Nos seus escritos e no doutros que o continuaron emprega uns conceptos realmente importantes, os derivados da xeopolítica. Cómpre interpretar a historia, a identidade e a puxanza contemporánea dos pobos, das nacións, para formular unha proposta de ancoraxe no mundo internacional de relacións.

$\mathrm{Na}$ nosa opinión, outros aspectos fundamentais do seu pensamento son o nacionalismo. Como xa dixemos, a defensa da nación galega xorde do significado británico de nación, a partir dos exemplos de Gales ou Escocia. Nación identitaria, cun pobo cohesivo que a singulariza e que pode seguir un camiño ceibo, independente como a República de Irlanda, ou integrado nun Reino Unido como Gales. E Galicia como nación que sempre debe ollar eses referentes. Tamén é fundamental para el o celtismo, non tanto pola exactitude histórica do mito, senón pola irmandade atlántica e fisterrá que implica este cualificativo empregado para as nacións, a música e a cultura. Por último, a paradiplomacia, 
a necesidade de establecer e reforzar os lazos cos países irmáns de calquera xeito, aínda que os aparellos estatais se desentendan. Mostrar Galicia como unha realidade propia igual que fixemos hai máis de dez anos en Dublín era unha homenaxe inconsciente ao legado de Plácido Castro, agora procuramos facelo de xeito consciente. 


\section{REFERENCIAS BIBLIOGRÁFICAS}

ANDERSON, B. (1983): Imagined Communities: reflections on the origin and spread of nationsalism, Londres, Ed. Verso.

BARGALLÒ, J. / S. Castellà / I. Mari (2013): Globalism versus Internationalism, Bruxelas, Centre Mauritius Coppieters, Papers 2013/2.

BeL, G. (2010): España, capital París. Origen y apoteosis del Estado radial: del Madrid sede cortesana a la «capital total», Barcelona, Ed. Destino.

Bermejo Barrera, J. C. (1982): Galicia y los griegos, A Coruña, Ed. Sálvora.

Cabero Diéguez, V. / J. I. Plaza Gutiérrez (1997): Cambios regionales a finales del siglo XX, Salamanca, AGE / Departamento de Geografía, Universidad de Salamanca.

Castelao, A. D. (1944): Sempre en Galiza, Bos Aires, Artes Gráficas Bartolomé U.

CASTro, P. (2016): «Irlanda libre (y otros textos)», Geopolitica(s), 7:2, 301-307.

COMISIÓN EUROPEA (1994): Europa 2000+. Cooperación para la ordenación del territorio europeo, Luxemburgo, Comisión Europea.

CRieKmans, D. (2010): «Regional sub-state diplomacy today: an introduction», The Hagur Journal of Diplomacy, 5:1, 1-9.

FARINELLI, F. (2009): La criso della ragione cartografica, Torinon, Ed. Einaudi.

Grydehoj, A. et al. (2014): Paradiplomacy, Bruxelas, Centre Mauritius Coppieters.

Huetz De Lemps, A. (1967): Vignobles et vins du Nord-Ouest de l'Espagne, Bordeus, Les Impresions Bellenet.

Kaplan, R. L. (2013): La venganza de la geografía. Como los mapas condicionan el destino de las naciones, Barcelona, RBA Eds.

Lois GonzÁLEZ, R. C. (2002): «As relaçons de Portugal com a Ibéria. Uma olhada desde a Galiza», Lusotopie. Portugal, une identité dans la longue durée, 10, 2002/2, 193-211.

LOIS GonZÁLEZ, R. C. (2015): «Apuntamentos para o estudo xeográfico (nacional) de Galiza», en VV.AA., Reflexións arredor da Galiza para o debate, Santiago de Compostela, Fundación Moncho Reboiras, 9-37.

López Trigal, L. / P. Benito del Río (1999): Geografía politica, Madrid, Ed. Cátedra.

MÉndeZ FernándeZ, F. (1993): «La domesticación del paisaje durante la Edad del Bronce gallego», Trabajos de Prehistoria, 51:1, 77-94.

Nogué Font, J. / Vicente Rufí, J. (2000): Geopolítica. Identidad y globalización, Barcelona, Ed. Ariel.

Portela, E. / Pallares, M. ${ }^{a}$ C. (1981): «Idade Media», en VV.AA., Historia de Galiza, Madrid, Caixa de Aforros de Galicia, 61-139.

Ríos, X. (coord.) (2002): Plácido Castro no centenario, Baiona, IGADI.

Ríos, X. (coord.) (2004): Galicia, un país no mundo, Sada (A Coruña), Ediciós do Castro.

Romero Masía, A. (1976): El hábitat castreño: asentamientos y arquitectura de los centros del NO. Peninsular, A Coruña, Ed. COAG.

Romero, J. (coord.) (2004): Geografia humana. Procesos, riesgos e incertidumbres en un mundo globalizado, Barcelona, Ed. Ariel.

TaYlor, P. J. (1994): Geografia Política: Economía-Mundo, Estado-Nación y Localidad, Madrid, Trama Ed. Trillo Santamarina, J. M. / R. C. Lois González (2016): «Comentario. La visión de Galicia de Plácido Castro: la interrelación entre la (geo)política interna y la externa», Geopolítica(s), 7:2, 309-317.

Vicens Vives, J. (1970): Aproximación a la Historia de España, Barcelona, Ed. Salvat. 
PLÁCIDO CASTRO E 0

UNIVERSALISMO GALEGUISTA

\section{Xulio Ríos}

Comisión de Acción Exterior do CCG 

Referirse á dimensión universalista de Plácido Castro ten, para min, dous significados principais. Desde unha perspectiva histórica, Plácido encarna mellor ca ninguén a «Galicia, célula de universalidade» que o Partido Galeguista (PG) converteu nun dos emblemas principais do seu programa. Lembremos que o PG reivindicaba unha Galicia revitalizada arredor de catro vigas: unidade cultural, pobo autónomo, comunidade cooperativa e, finalmente, célula de universalidade, facendo fincapé neste último caso en tres aspectos: pacifismo, federalismo internacional e antiimperialismo.

Non era este un principio menor para os galeguistas que poñían en contraste o pacifismo das nacións pequenas fronte ás dinámicas expansionistas e agresivas dos grandes estados — naquel tempo inmersos en fondas tensións_- que defendían o libre consentimento das comunidades nacionais como base de calquera proposta federal e que situaban o imperialismo como antítese da liberdade.

Desde o punto de vista actual, ten todo o sentido reivindicar o universalismo fronte á uniformización que vén da man dun concepto abafante de mundialización, ou reivindicar a convivencia multicultural fronte ás políticas de asimilación que diferencian entre culturas dominantes e dominadas. A protección do ecosistema cultural global é parte dese discurso compartido e promovido polos galeguistas de inserirnos no mundo con identidade propia, sen querer ser máis ca ninguén, pero tampouco menos.

O universalismo non é un principio superado polo devir dos tempos. Todo o contrario. E cumpriría poñelo ao día. 


\section{AS IDEAS CENTRAIS DE PLÁCIDO CASTRO}

Cales son as ideas centrais de Plácido Castro neste aspecto?

O primeiro que cómpre dicir é que o noso autor amosou desde moi novo un pensamento ben estruturado. Considerado unha persoa de moita cultura e un intelectual de primeira, Plácido Castro amósase como unha figura singular, unha rara avis, no mundo galeguista da época. En primeiro lugar, pola súa orixe acomodada, infrecuente nun contorno maiormente de clase media. O seu pai era empresario de minas, armador de buques e estaba relacionado cos abastecementos de carbón ao Reino Unido, sendo tamén vicecónsul de Suecia e Noruega en Corcubión. En segundo lugar, por unha formación anglófila que contrastaba coa tendencia maiormente xermanófila dese mesmo contorno. Plácido Castro formouse no Reino Unido, no colexio Scarborough e na Universidade de Glasgow, nun ambiente frecuentado pola realeza británica e por figuras como G. K. Chesterton, quen exerceu nel unha fonda impresión. Plácido cursou primeiro estudos de Arquitectura Naval (probablemente seguindo as indicacións e preferencias familiares), que abandonou, e cabe imaxinar que se licenciou en Filoloxía Inglesa na Universidade de Glasgow, un extremo aínda por confirmar, ou en Cambridge, onde tamén estudaría.

A súa erudición, co dominio de varias linguas, amplos coñecementos de poesía, astronomía, música, pintura etc., convertíao nun humanista por excelencia. Os galeguistas entón orientaban os seus pasos cara á Europa máis avanzada sen pasar por Madrid.

a) A primeira variable que hai que considerar é como un señorito de Corcubión con eses antecedentes puido achegarse ao galeguismo. No meu parecer hai dous factores esenciais. Plácido chega ao nacionalismo dando un rodeo polo Reino Unido. Non é por «vitimismo»; isto é, normalmente un facíase galeguista tomando conciencia do maltrato que o Goberno central lle dispensaba a Galicia e por considerar que o único camiño de superación desa realidade pasa por contar con forzas propias para defender os nosos intereses como comunidade. Pola 
contra, a pregunta central que Plácido fai a si mesmo é: como un país tan pequeno coma o Reino Unido pode progresar e ter tanta influencia no mundo? E responde: non depende da demografía ou do tamaño, senón da autoestima, da conciencia do propio, do coñecemento das potencialidades e posibilidades dun mesmo, do desenvolvemento das propias capacidades. É dicir, a clave de fondo é o rexeitamento das imitacións, do tipo de que sexan, e o afincamento na propia realidade para avanzar a partir dela, sendo creador a partir do que un é. Esa é unha idea substancial no pensamento de Plácido: só pode haber progreso desde a identidade, desenvolvéndoa, construíndo a partir dela.

Outro factor que inflúe na conformación do seu galeguismo son as súas estadías de verán en Galicia e os contactos e conversas mantidas con Antón Villar Ponte. É entón cando reforza as súas conviccións e chega á conclusión de que quen defende mellor os seus puntos de vista é o galeguismo, que responde a esa idea de que o progreso dun pobo debe repousar na reivindicación e actualización permanente da súa identidade a todos os niveis. Esa é a proposta política do galeguismo. E nese concepto de identidade non só debemos considerar a lingua, a cultura, o folclore, naturalmente, senón os nosos sectores produtivos, o noso agro, industria, comercio etc.

E nese marco, elaborando e desenvolvendo un discurso político innovador, Plácido rebenta tópicos: cúrase o nacionalismo viaxando? É o galego unha lingua sen futuro? Plácido faise galeguista no Reino Unido e aprendendo inglés, lingua que chegou a dominar con gran habelencia, sen que iso supoña contradición ningunha.

b) En segundo lugar, se Galicia quere ser quen é, se os galegos queremos existir sendo nós mesmos para progresar con firmes raíces no noso, debemos afondar na nosa identidade, acometer un labor de introspección que identifique as nosas valías. E Plácido bota man entón de dous elementos que considera substanciais para reforzar as particularidades de Galicia. Un é o celtismo. O outro é a saudade. Ambas as escollas terán implicacións para a xeopolítica galega, que tamén definirá. 
En efecto, o celtismo acompañaríao toda a vida. Plácido realizou un seguimento moi activo da problemática dos pobos célticos, moi especialmente de Irlanda. Naquel tempo, moitos galeguistas evocaban o exemplo do nacionalismo irlandés, pero só Plácido visitou Irlanda, mesmo chegou ata os confíns das míticas illas Blasket. Alén diso, en moitas das súas crónicas xornalísticas desde Londres, que iniciou en 1927 no diario El Pueblo Gallego, recorría á vida política irlandesa para ilustrar sobre as escollas que debía facer o galeguismo para seguir medrando no seu proxecto político.

Das crónicas da viaxe que realizou a terras irlandesas en 1928 dedúcese con fundamento que Plácido sentía unha enorme simpatía por Irlanda, a «irmá celta asoballada», tanto no plano erudito (con especial mención do afán celtista) coma estético (desde a arte, o teatro ou a poesía, naturalmente). Gráfico é o seu esforzo por trasladar a un pentagrama as melodías cantadas polos habitantes das illas Blasket, hoxe referencia mítica da sociedade irlandesa.

Plácido emocionábase con Irlanda e acompañou de preto a construción do novo Estado, sempre con xuízos asisados, cheos de matices, sinalando a complexidade que rodeou aquel proceso, tan interesante por outra banda para unha Galicia onde el adiviñaba moitas semellanzas (a pobreza, a emigración, a significación da cultura antiga, a política británica como calco en tantos aspectos da política centralista española...).

O estudo e coñecemento de Irlanda axudoulle enormemente a conformar o seu pensamento político a prol do rexurdimento galego. Tiña en Irlanda Plácido ao seu dispor todo un viveiro de experiencias nos máis diversos temas (as dicotomías cidade-aldea, ou agricultura-industria, a lingua e o seu futuro, a política de alianzas...) que proporcionaban argumentos de peso para tomar posición ante os grandes dilemas do galeguismo nos anos trinta do pasado século.

Irlanda non só inzou a Plácido de razóns para desmontar punto por punto os argumentos contra as reivindicacións autonomistas dos galeguistas na época senón que influíu sobranceiramente na súa concepción da política exterior que reclamaba para Galicia, outro dos epítomes dun pensamento que o distingue 
entre os seus coetáneos, mesmo respecto a aqueles que compartían con el esa vocación universalista.

A saudade é outra das querenzas fundamentais de Plácido á hora de destacar trazos específicos da nosa identidade. Plácido fala da saudade como a nosa forza, como o instinto da vida, moi lonxe da caracterización pusilánime que se fai habitualmente. Castelao, no Sempre en Galiza, cando fala da saudade, ese sentimento que une galegos e portugueses, bota man de Plácido para ilustrar o seu significado e reivindicar a súa procedencia como activo sociocultural do país. No ensaio sobre a arte e a saudade nos pobos célticos realiza unha defensa incontestable da saudade como inspiración fundamental da arte céltica.

Para Plácido, a principal xustificación da existencia do nacionalismo galego residía na persistencia do espírito celta na alma do pobo a través de tantos séculos de infortunio e de dominación estraña. E defendía con vigor a idea de que para buscar inspiración en literaturas e mitoloxías de fóra de Galicia non precisamos ir a Grecia, abóndanos con estudar as de Escocia, Irlanda e Gales para descubrir unha cultura lendaria tan rica e tan marabillosa coma a grega, e que posúe maior afinidade co noso carácter. Plácido destaca a inmensa valía intelectual do pensamento céltico, que considera unha das bases indiscutibles do acervo común da civilización europea.

En resumo, para Plácido, os nosos pretendidos «deméritos» son tesouros nos que debemos fincar o noso esforzo. Quizais por iso non dubida en lle facer un expreso convite á «burguesía galega» para que contribúa a poñer en valor e dignificar o propio antes de caer no pailanismo de desprezar o noso, tantas veces de superior calidade ao doutros.

Outro tanto podiamos dicir do eloxio que fai da dúbida que supostamente nos caracteriza como hipotética expresión da indecisión que se nos imputa. Pola contra, Plácido destaca o valor da dúbida como instrumento para chegar ao fondo dos problemas, reforzar os nosos argumentos, buscar consensos e tomar decisións asisadas. Unha mostra, en resumo, de sagacidade, rigor e habilidade que moitos quererían para si como patrón de comportamento. 
A ecuación que o resume todo é unha aposta inquebrantable pola recuperación da autoestima en todas as súas variables proscribindo esa autodestrución que sempre nos acompaña e que parte de que o noso é sempre inferior ao alleo. Desde a súa altura intelectual e ampla formación, Plácido convida a unha formulación en positivo das posibilidades de Galicia. Contra ninguén. Partindo de nós mesmos. «Ou crear unha vida propia ou seguir sendo imitadores. E o que é peor: imitadores de imitadores, europeos de segunda man», dicía.

c) Unha terceira idea é que o nacionalismo é un credo moderno, como titulou a súa conferencia na Coruña en 1931. Nada de política retrógrada. Plácido concibe o nacionalismo como outra forma de unión, non como unha proposta para erguer valados fronte a outros. Trátase de conformar novas unidades sobre outras bases sinalando o nacionalismo como punto de contacto co mundo. Así foi que aquel galeguismo era certamente do máis avanzando en moitos aspectos, xunto con outros nacionalismos do Estado, na política española da época.

Descarta absolutamente que o nacionalismo das pequenas nacións sexa un movemento político de corte violento. Pola contra, libera enerxía positiva e debilita o imperialismo, auténtico causante das guerras. Non son as pequenas nacións que arelan a súa liberdade as que provocan os conflitos armados senón o afán esmagador de quen as reprime.

Por último, sinala que o nacionalismo é unha política especialmente idónea para fortalecer o ideal democrático pois contribúe a facilitar o logro de acordos cun maior nivel de participación cívica e achegando as decisións ás propias comunidades que as deben observar e implementar.

d) Un cuarto elemento que hai que considerar é a súa reivindicación dunha acción exterior propia. Plácido Castro é o noso principal referente neste eido pois formulou os principios da nosa paradiplomacia hai 90 anos. Noutro país calquera esta soa circunstancia sería motivo de respecto e certa veneración; en Galicia, hoxe, nesa Galicia que renega do propio, pola contra, serve de ben pouco.

Nun artigo publicado en agosto de 1933 no diario El Pueblo Gallego, Plácido traza as orientacións básicas da nosa política exterior, significando tres obxectivos preferentes. En primeiro lugar, Euskadi e Cataluña, no marco de Galeuzka, 
con dúas liñas perfectamente definidas: unha cara ao Estado e outra cara a Europa. Plácido «importa» do Reino Unido aquela idea de que o mellor xeito de garantir a lealdade á Coroa consiste en exaltar os diferentes nacionalismos, unha idea que expresa ao comentar a inauguración do Museo Nacional de Gales. A preocupación pola proxección europea lembra que os galeguistas eran dos máis europeístas no seu tempo. Non era casualidade que Lois Tobío fora alcumado «el europeo» polos seus compañeiros de promoción da carreira diplomática. As miradas dos galeguistas e dos nacionalistas vascos e cataláns fixaban a súa atención no Congreso de Nacionalidades Europeas.

A segunda orientación eran os pobos da área de influencia de orixe lusitana, moi especialmente Portugal e Brasil. Plácido pon en valor os vínculos lingüísticos para desenvolver unha acción exterior específica no contorno do que hoxe coñecemos como a lusofonía pero sen descartar a «natural irmandade» coas nacións americanas de fala castelá e ata con Filipinas, esbozando mesmo que «o conxunto formaría unha verdadeira Sociedade de Nacións con posibilidades de universalismo igualada soamente polo conxunto de pobos de fala inglesa» (velaí a formulación da Comunidade Iberoamericana de Nacións). E idea mesmo a posibilidade de desenvolver un marco de cooperación neste ámbito con Portugal similar ao que vascos e cataláns poderían desenvolver con relación ás comunidades galas do outro lado dos Pireneos. En resumo, un avance do que hoxe entendemos como cooperación transfronteiriza, un dos alicerces fundamentais da Unión Europea.

Por último, Plácido chama a atención sobre a importancia de trazar unha cooperación activa coas terras célticas de Europa, é dicir, construíndo o celtismo cara a dentro e cara a fóra, unha imaxe que nos evoca actualmente o perfil do chamado Arco Atlántico da UE, do que Galicia forma parte.

O mapa que Plácido nos traza para desenvolver a nosa acción exterior é o dun país aberto ao mundo, un país liderado por un galeguismo que aspira a que sexamos parte de xeito práctico, humano e moderno dun universalismo afastado daquela outra idea baseada «nas xestas históricas da España imperialista». 
d) A concepción das relacións internacionais que alenta Plácido Castro ten tamén algúns aspectos de interese. É unha concepción esixente e crítica cando nos di que «a diplomacia é unha cousa tan delicada que non resiste a presenza da verdade». A política exterior debe ser soporte de ideas como transparencia, pacifismo ou democratización.

Chama a atención que xa entón reivindicaba, por exemplo, unha fiscalización social da política exterior precisamente para evitar que os Estados adoptasen decisións de costas a unha cidadanía que debía soportalas con resignación no marco dunha alta política desenvolvida en segredo e que lle era furtada.

Igualmente, Plácido reivindica un sistema de xustiza internacional que garanta o respecto do principio de legalidade en calquera momento e lugar.

\section{O IX CONGRESO DE NACIONALIDADES EUROPEAS}

Alén das ideas e o discurso, no que paga a pena profundar porque ofrece trazos ben singulares no cosmos galeguista da época, a fotografía fixa, por así dicilo, que resume a significación de Plácido Castro para Galicia e o universalismo galeguista é a súa participación no IX Congreso de Nacionalidades Europeas (CNE) que tivo lugar en Berna en setembro de 1933.

$\mathrm{O}$ recoñecemento internacional de Galicia como unha nación foi sempre unha arela dos galeguistas, xa presente nas Irmandades da Fala en 1918. Daquela, amentábanse dúas vías principais: a revolucionaria da Liga contra o Imperialismo e pola Independencia Nacional e a legal, representada polo Congreso de Nacionalidades Europeas, que funcionaba baixo o principio de lealdade das minorías e que polo tanto aspiraba a un mellor e maior recoñecemento das comunidades nacionais excluíndo a secesión.

O CNE xorde en 1925 en Xenebra co auxilio das minorías nacionais alemás e húngaras presentes en numerosos estados europeos como resultado dos movementos fronteirizos das décadas precedentes. O CNE mantiña unha estreita 
relación coa Sociedade das Nacións, que xurdira tras a fin da Primeira Guerra Mundial.

Desde 1925 ata finais dos anos trinta constituíron unha referencia importante para advertir a persistencia de problemas nacionais en Europa que estaban aínda pendentes de resolución e para reclamar a atención permanente dos estados sobre a imperiosa necesidade de salvagardar o respecto dos dereitos elementais das minorías.

A iniciativa da creación deste movemento correspondeu aos grupos alemán e maxiar, destacando na súa consolidación o rol individual de quen foi o seu presidente desde o primeiro momento, o deputado esloveno do Parlamento italiano, Josip Wilfan, personalidade carismática e de gran capacidade aglutinadora. A representación do Congreso era compartida cun secretario xeral, Ewald Ammende, estoniano, xornalista do Revaler Bote e do Rigasche Rundschan.

A amplitude e intensidade da presenza e o grao de influencia das minorías xermanas existentes en varios estados europeos apreciábanse, principalmente, no indiscutible papel do idioma alemán como vehículo fundamental dos debates e documentos impulsados desde o Congreso. E sería no futuro, no marco da complicada evolución europea dos anos trinta, causa decisiva do camiño sen saída no que se precipitou a organización.

O congreso fundacional tivo lugar en Xenebra, do 14 ao 16 de outubro de 1925. Participaron 50 delegados de 27 grupos nacionais organizados e pertencentes a 10 estados diferentes (Checoslovaquia, Iugoslavia, Romanía, Polonia, Alemaña, Austria, Italia, Letonia, Estonia e Lituania), que representaban un total aproximado de dez millóns de persoas. Nel establecéronse como principios fundamentais os seguintes:

a) A liberdade nacional é, como a liberdade relixiosa, un ben espiritual do mundo civilizado. Todo Estado en que convivan diversos grupos nacionais debe ser obrigado a lles garantir a esas colectividades a liberdade de 
desenvolvemento cultural e económico, e aos seus membros o gozo ilimitado dos seus dereitos cívicos.

b) O dereito de autonomía considérase unha vía idónea para propiciar a cooperación entre as minorías e as maiorías, para que as relacións entre os pobos de Europa sexan melloradas e poidan desenvolverse sen conflitos.

c) A Sociedade das Nacións deberá ocuparse dunha maneira máis extensa da solución do problema nacional no que atinxe á realización dos dereitos das minorías.

Un principio esencial desta organización é o coñecido como de loyauté des minorités (lealdade das minorías). Quere dicir que o obxectivo do CNE e das agrupacións que nel se integran é exercer presión nos gobernos para que os dereitos das minorías sexan respectados pero excluíndo manifesta e expresamente os ataques directos e así mesmo as declaracións de carácter irredentista.

Desde o primeiro momento, o CNE mostrou o seu desexo de colaborar activamente coa Sociedade das Nacións, a ONU de entreguerras, para resolver os conflitos que enfrontaban a algúns estados coas minorías que coexistían no seu territorio e igualmente contribuíndo ao perfeccionamento e mellora do tratamento legal desta problemática, tanto no plano internacional coma estatal.

O CNE procurou a presenza dun representante da Sociedade de Nacións (SDN) en todos os congresos e as resolucións adoptadas transmitíanselle puntualmente para o seu coñecemento e efectos.

$\mathrm{O}$ ano en que se desenvolveu o IX Congreso de Nacionalidades Europeas (1933) foi abondoso en acontecementos que influíron decisivamente na intensificación e agravamento da crise que asolaba o continente. En xaneiro, o presidente alemán Paul von Hindenburg designaba primeiro ministro a Adolf Hitler, líder do Partido Nazi, que dez anos antes protagonizara unha tentativa de golpe de Estado. Nas eleccións lexislativas de 1930 converteranse na segunda fracción parlamentaria despois dos socialdemócratas, e nas presidenciais realizadas en 1932, Hitler disputáballe a Hindenburg, nunha pelexada segunda volta, a presidencia de Alemaña. 
O IX CNE desenvolveuse en Berna durante os días 16, 17 e 18 de setembro de 1933. A sede do Secretariado do Congreso situouse no hotel Savoy da capital suíza. A orde do día foi a seguinte:

- Discurso de apertura do presidente.

- «Desasimilación» nacional e dereitos das nacionalidades.

- Os dereitos, e especialmente en materia de idiomas, das nacionalidades na vida das colectividades relixiosas.

- Actividade da SDN no decurso do pasado ano en materia de protección das minorías nacionais.

- A cuestión do self-gouvernement (autogoberno) para os territorios de poboación alóxena unida.

- Esencia e desenvolvemento da colectividade nacional.

- Cuestións de organización.

As sesións tiveron lugar nas salas do Pazo Federal (Sala do Gran Consello). Segundo a orde do día distribuída no congreso o sábado 16 de setembro, pola tarde, e despois da intervención inaugural do presidente Wilfan, estaba prevista a declaración do deputado Otero Pedrayo, representante do novo grupo galego de España que neste ano se sumaba ao congreso como novo membro. Otero non asistiría e sería Plácido Castro quen desempeñaría a representación en solitario.

Os grupos que nesta altura forman parte do congreso son os seguintes: grupo vasco de España; grupos búlgaros de Romanía e Iugoslavia; grupos alemáns de Estonia, Letonia, Lituania, Polonia, Dinamarca, Checoslovaquia, Hungría, Iugoslavia, Romanía e Italia; grupo grego de Italia; grupos xudeus de Estonia, Letonia, Lituania, Polonia, Checoslovaquia, Romanía e Bulgaria; grupos iugoslavos (eslovenos e croatas) de Italia e de Austria; o grupo catalán de España; os grupos lituanos de Polonia e de Alemaña; os grupos ucraínos de Polonia e de Romanía; os grupos húngaros de Checoslovaquia, Iugoslavia e de Romanía; os grupos rusos de Estonia, Letonia, Lituania, Polonia, Chechoslovaquia (Carpatorrusia) e de Romanía; o grupo sueco de Estonia; o grupo checoslovaco de 
Austria; o grupo eslovaco de Hungría, e o grupo rusobranco ou bielorruso de Polonia.

A oportunidade de convocar o congreso fora obxecto de debate entre os dirixentes da entidade desde a primavera. Era doado prever que os acontecementos de Alemaña e a nova política do seu Goberno en relación coas nacionalidades e minorías acabarían por afectar moi fondamente á sorte do congreso. Nunha reunión do Buró de dirección do CNE realizada en Viena no mes de abril, manifestáronse fortes presións contra a idea da convocatoria neste ano e propúxose o aprazamento para 1934. Os partidarios desta alternativa argumentaban que era mellor agardar a ver que pasaba en Alemaña pois o CNE non resistiría unha discusión que, por outra banda, era inevitable verbo dun elemento tan considerablemente importante na súa organización como o elemento xudeu.

Ewald Ammende, co apoio do presidente Wilfan, quizais por medo a que unha suspensión temporal puidese converterse en definitiva por imponderables históricos, consideraba posible e necesario que o CNE favorecese un encontro de representantes moderados alemáns e xudeus, avogando por un entendemento conciliador. O grupo alemán era o máis numeroso do CNE (con minorías en sete países) e máis potente desde o punto de vista político e asegurador tamén da maior parte do financiamento da Secretaría Xeral. Os xudeus demandaban un pronunciamento contra a política de Alemaña en relación coa súa minoría. Se os xudeus abandonaban o CNE, os alemáns terían tanta influencia que os demais grupos probablemente optarían por abandonar o CNE ante o temor de ser utilizados.

En ausencia dos representantes xudeus, Mr Wilfan abriu o congreso. O decorrer da sesión levou a que os xudeus lle dirixiran unha carta ao presidente con data 17 de setembro comunicando que se estaba a crear unha situación que destruía as condicións esenciais para posibilitar a súa colaboración no seo do congreso. $\mathrm{O}$ texto foi lido parcialmente aos asistentes, o que levou a un observador xudeu asistente ao evento a distribuír inmediatamente exemplares na sala contigua á da conferencia, reproducindo a totalidade do texto. 
En medio de múltiples tensións que levaron a conferencia ao bordo da ruptura, desde o Buró promoveuse unha declaración segundo a cal «o conxunto de medidas de carácter netamente antisemita que poden observarse en certos países é considerada por estes grupos como contraria aos dereitos xerais do home e aos ideais do congreso». Os alemáns entón reaccionaron exhibindo a posibilidade de abandono, que finalmente non se produciu.

Leo Motzkin, presidente executivo do comité das delegacións xudías, foi reelixido membro do Buró directivo do CNE, quizais coa ilusoria esperanza de que a súa saída non podía ser definitiva.

\section{A PARTICIPACIÓN GALEGA}

A participación da representación galega no congreso de 1933 xestouse no marco da asistencia previa de Otero Pedrayo ao Aberri Eguna dese mesmo ano. Foi entón cando tomou contacto con Ewald Ammende, secretario do congreso, quen foi convidado a visitar Galicia, cousa que fixo.

O semanario A Nosa Terra, portavoz do Partido Galeguista, informou en varios números desa participación galega. A valoración non ofrecía dubidas:

Cando en Hespaña se nos nega toda persoalidade, cando se nos inxuria e se nos desprecia, que se oia a nosa voz autóctona e persoal no gran concerto dos pobos, que como tales, en esprito i en xusticia, poidamos dialogar con dignidade con nacións irmáns niste arelar infindo de futuros, é algo que ten de soerguer o noso esprito de todo iste patuxar en somas lamentas en que decote vimos loitando con todo o cerrilismo mais burdo (ANT 311, 25 de setembro de 1933).

O acontecemento non dubida en considerarse como unha efeméride fundamental para o nacionalismo galego porque con iso asegúrase que a xustiza da causa galega quedase recoñecida por esa ducia de nacionalidades participantes do congreso, segundo recollía A Nosa Terra ou El Pueblo Gallego. 
Para os galeguistas, a asistencia ao congreso de Berna perseguía como obxectivos fundamentais: a procura de apoio moral da opinión pública internacional (segundo Plácido, a nova da participación galega foi recollida pola prensa europea) diferenciando esta da axuda política para resolver problemas que en principio soamente lles cómpre dilucidar aos galegos, o establecemento dun marco de cooperación estreito cos movementos afíns que permitisen a universalización de Galicia no dobre senso de facer que Europa nos coñeza e de nós coñecer mellor a Europa, e, finalmente, o recoñecemento da condición de nación por parte dun organismo internacional coma este, de considerable prestixio e reputación.

$\mathrm{Na}$ crónica da participación na prensa galega informouse do tratamento e estudo das moi interesantes cuestións de orde internacional que lles afectan intimamente a todas as pequenas nacionalidades.

Ademais de referirse aos elevados niveis de participación observados no congreso, Plácido relatou as numerosas cuestións que foron obxecto de estudo e discusión por parte dos presentes: a situación na Ucraína soviética, das minorías da Alta Silesia, do problema xudeu, dos emigrados alemáns e tamén o asunto relativo á redacción dun convenio internacional sobre a protección e liberdade de todos os cidadáns e cidadás dun Estado con independencia da súa raza, idioma ou relixión.

Entre as resolucións aprobadas, Plácido destacou dúas: unha na que se afirma que o xeito mais doado de resolver os problemas das minorías consiste na implantación da máis ampla autonomía, e outra sobre a necesidade de que o ensino da relixión se faga na lingua dos fieis.

$\mathrm{Na}$ declaración presentada pola delegación galega á consideración do congreso proclámase que Galicia é unha nación ben definida, ao tempo que se reivindica o dereito innegable do pobo galego a dispor de si mesmo, e na liña das disposicións internacionais relativas ás minorías, reclama a plena liberdade de empregar o seu idioma materno, sobre todo no ensino, e así mesmo o respecto dos seus costumes. 
$\mathrm{Na}$ memoria redactada por Vicente Risco informábase aos agrupamentos que formaban parte do congreso das características do noso país a todos os niveis. O documento constitúe unha intelixente e ordenada exposición que desde a primeira á derradeira frase sinala dous obxectivos claros: clarexar que o caso galego é perfectamente asociable ao doutras minorías europeas que non consideran suficientemente recoñecidos uns dereitos elementais e, así mesmo, que esa situación se enmarca nun contexto de fonda discriminación por parte do Goberno do Estado e causa cuantiosos danos económicos e de toda índole.

Contou igualmente Plácido Castro que a representación galega foi acollida cordialmente tanto polo presidente do congreso, Josip Wilfan, coma polo presidente do Parlamento suízo, M. Motta, e formou parte do comité permanente do CNE na súa visita de cortesía ao primeiro ministro noruegués e presidente do Consello da Sociedade de Nacións, M. Mowinckel.

Tras o IX congreso, o Partido Galeguista mantivo a comunicación co CNE pero non asistiu a máis eventos. A situación en España e en Europa así como as tensións internas alentadas polo conflito entre as minorías alemás e xudías lastraron a efectividade da organización, que en 1938, en Estocolmo, celebraría o seu derradeiro encontro.

\section{VOCACIÓN POLÍTICA: UNHA DE TRES}

Ao longo da súa vida (1902-1967), Plácido desenvolveu tres vocacións principais.

A primeira foi o xornalismo, tanto antes coma despois da guerra. As súas primeiras colaboracións en El Pueblo Gallego, as «Crónicas desde Londres», iniciounas con apenas 25 anos, amosando nelas unha gran madurez e un profundo coñecemento da política británica. Nunha misiva de Valle-Inclán ao seu pai, que lle escribira interesándose pola súa opinión a propósito das colaboracións do seu fillo, recoñecía nel un «joven de provecho», unha "pluma fácil, ágil y despierta», pero cun «funesto sentido provinciano», debido a que consideraba unha perda 
de tempo andar coa vella teima do celtismo... Despois da guerra, Plácido colaboraría coa BBC, desde Londres, ou co Jornal de Notícias de Porto. Tras a volta a Galicia, as súas colaboracións sucederíanse en La Noche, Diario de Pontevedra ou, sobre todo, Faro de Vigo, que por aquel entón dirixía o seu amigo Álvaro Cunqueiro, en quen posiblemente influenciou coa súa cultura arredor dos mitos célticos. Se na primeira etapa primaba a análise política, na segunda era a cultura e temas conexos os que predominaban nas súas colaboracións.

A segunda vocación foi a tradución, unha constante moi relevante que combinaba co seu profundo amor pola poesía. En 1946, a Federación de Sociedades Galegas de Arxentina premiouno, xunto a Lois Tobío e Florencio Delgado Gurriarán. A súa tradución das Rubáiyát de Omar Kháyyám, a partir da versión inglesa de Fitzgerald, é moi celebrada. A súa figura é recoñecida como a dun dos grandes pioneiros da tradución en Galicia. Paga a pena mergullarse no volume preparado por Laura Linares, Verbas atlánticas, editado pola propia Fundación, onde se recolle, en versión bilingüe, esa inmensa obra que Plácido foi construíndo paseniñamente ao longo da súa vida. Sempre defendeu a idoneidade da lingua galega para a tradución poética e mesmo nos anos máis duros do franquismo non deixou de expresar en galego os seus poemas e autores estranxeiros favoritos.

Por último, a política. Plácido foi elixido membro do Comité Directivo do Partido Galeguista cando a súa fundación, en 1931. A partir de 1933, na Asemblea extraordinaria realizada en Ourense, desempeñou o cargo de secretario de Relacións Internacionais, en boa medida como recoñecemento do seu labor no IX Congreso de Nacionalidades Europeas. Naquela asemblea, Plácido foi o máis votado para a dirección polos delegados do Partido (1654 sufraxios). Alexandre Bóveda substituíno á fronte da secretaría de organización. Plácido participará en 1934 no Pacto de Compostela e asumirá a representación do Partido nas reunións de Galeuzka.

En canto á súa traxectoria, é perceptible con nitidez a existencia dun Plácido antes e despois da Guerra Civil (1936-1939). Antes da guerra, hai un Plácido entusiasmado e comprometido co ideal galeguista. Preside as Irmandades da Fala da Coruña, a Asociación de Escritores en Lingua Galega da cidade 
herculina, implícase a fondo na campaña a favor do Estatuto de autonomía para Galicia etc. En boa medida, dálles as costas aos plans familiares, que seguramente optaron por envialo a formarse ao Reino Unido coa esperanza de que continuase cos negocios que lle procuraran aquela vida acomodada, pero desenténdese totalmente dese rumbo e opta por implicarse a fondo no movemento de redención da identidade galega.

Tras a guerra, con 38 anos cumpridos, Plácido debe reorientar a súa vida. Pola súa militancia galeguista, é condenado a unha multa de 25000 pesetas, oito anos de desterro a $100 \mathrm{~km}$ de Muxía e 15 anos de inhabilitación absoluta. Opta por trasladarse a Vigo, onde vive primeiro na rúa Lepanto e despois na rúa Reconquista. Na Cidade Olívica mantense en contacto cos irmáns Álvarez Blázquez, con Fernández del Riego (con quen fixera a campaña polo Estatuto en Lugo) ou con Xaime Illa (con quen fundaría anos maís tarde a editorial Sept). A decadencia do negocio familiar e outras circunstancias, entre elas a asfixia imposta polo franquismo, lévano de volta ao Reino Unido. En Londres incorporase á $\mathrm{BBC}$, onde colabora nos programas en galego, castelán e inglés, entre 1948 e 1955 . Ao se cumpriren os 15 anos de inhabilitación regresa a Galicia e pasa a impartir clases de inglés no Instituto Laboral de Vilagarcía. Asenta en Cambados, onde o coñecido como «o inglés» casara en 1944 con Jesusa Sineiro Vidal.

\section{CONCLUSIÓNS}

O universalismo é parte substancial do ideario galeguista desde as súas formulacións iniciais. E non era cousa menor. Fronte aos partidarios daquel internacionalismo que o apostaban todo ao lema de que «todos somos traballadores» ou o cosmopolitismo baseado na idea de que «todos somos cidadáns do mundo», os galeguistas opoñen a vontade de «exercer de galegos no mundo». Esa era a súa visión do progreso, a modernidade e a solidariedade desde Galicia. 
E non só foi retórica e discurso. O galeguismo deu pasos prácticos nesa liña. En primeiro lugar, prestando unha significativa atención nos medios de comunicación propios ao acontecer mundial, en especial a aqueles conflitos ou tendencias que poderían ser de especial atención para a causa galega. Trátase así non só de crear conciencia senón mesmo de facer pedagoxía ante unha cidadanía que cumpría entusiasmar co seu ideario. En segundo lugar, da man de vascos e cataláns, cada un cos respectivos ritmos e tendo en conta os diferentes tempos, coordinar accións para situarnos no mundo con identidade propia atendendo a unha definición dos espazos xeopolíticos de maior proximidade para nós.

Tiñan os galeguistas unha percepción clara, primeiramente, da crise do modelo de Estado centralista. Este necesariamente debía organizarse de xeito que considerase a realidade nacional sobre a que actuar, se ben isto podía traducirse de diferentes xeitos. A conciencia sobre a necesidade de transformación do Estado abarcaba un aspecto esencial da política exterior dos galeguistas que conducía Plácido Castro. Neste senso, o modelo de Galeuzka continúa sendo, onte coma hoxe, plenamente necesario e conveniente para Galicia. O PG soubo coordinar admirablemente as necesidades históricas coas posibilidades reais con que contabamos, inferiores a outras realidades nacionais peninsulares.

Outro aspecto que hai que destacar é a proclamación de Galicia como unha nación europea. Alén do feito histórico e simbólico, o acontecemento é sobradamente revelador sobre a localización do noso país no contexto internacional. Non menos importante é a estratexia utilizada para inserirse en Europa: da man dos vascos e cataláns, mesmo como unha prolongación do acordo acadado na península.

Por último, no desenvolvemento desa mentalidade universalista do galeguismo, Plácido desempeñou un papel esencial. E non só na política, aínda que fora nesta na que se manifestara de maneira nítida nun primeiro momento. E non só antes da guerra, aínda que este fora un período especialmente fértil. Plácido era un universalista integral. Para el, o universalismo era unha forma de vida que está moi presente nas súas tres vocacións principais, no xornalismo, na tradución 
ou na defensa da identidade nos dominios en que puido facelo, pulando sempre pola dignificación e posta en valor do noso.

Plácido tiña formación, ideas e discurso propio; era un home de mundo que militaba a favor dun progreso con raíces. Para el non había fronteiras, nin políticas nin no coñecemento. E non entendía ese mundo sen un país, o seu, Galicia. 


\section{REFERENCIAS BIBLIOGRÁFICAS}

Castelao (1944): Sempre en Galiza, Bos Aires, Ediciós Galiza.

CASTRO, Xavier (1985): O galeguismo na encrucillada republicana, Ourense, Deputación, vols. I e II.

Estévez, Xosé (2019): «O Galeuzka e Plácido Castro», en XIX Conferencia Anual, Rianxo, 25 de xaneiro de 2019, accesible en: http://www.fundacionplacidocastro.com/conferencia-anual/20a-conferencia-anual-placido-castro-o-galeuzca-e-placido-castro

Ríos, Xulio (1992): Galicia e a Sociedade das Nacións, Vigo, Galaxia.

Ríos, Xulio (1997): Plácido Castro, Vigo, Ir Indo Edicións. (Colección Galegos na Historia).

Ríos, Xulio (2010): Nós no mundo. Unha politica exterior para Galicia, Vigo, Galaxia.

Ríos, Xulio (ed.) (2011): Irlanda en Plácido Castro, IGADI.

Ríos, Xulio (coord.) (2004): Galicia, un país no mundo, Sada (A Coruña), Ediciós do Castro.

Toro Santos, Antonio Raúl de (1994): Galicia desde Londres, A Coruña / Santiago de Compostela, Tambre / Xunta de Galicia.

Villares PaZ, Ramón (2004): Historia de Galicia, Vigo, Galaxia.

VV. AA. (2002): Plácido Castro no centenario, IGADI.

VV. AA. (2006): Congreso sobre Plácido Castro e o seu tempo, Santiago de Compostela, Xunta de Galicia. 
Plácido Ramón Castro del Río (Corcubión, 1902-Cambados, 1967) foi unha figura moi singular no galeguismo por varias razóns. Non era habitual neste movemento a presenza de persoas procedentes dunha clase social moi acomodada. Por outra banda, no seu compromiso galeguista influíu longamente a observación e o coñecemento profundo da vida política británica e irlandesa, sen que iso o levase a ignorar ou desprezar o propio. Finalmente, desenvolveu, na teoría e na práctica e máis ca ninguén no seu tempo, a idea da inserción internacional de Galicia, definindo os eixes básicos dunha política exterior de vocación universalista.

Na formulación dun progreso con identidade está a clave do seu pensamento. A defensa da identidade en Plácido Castro non o levaba a ser conservador, senón a promover unha idea de progreso que non destruíse aquilo que fai a Galicia e aos galegos e galegas diferentes dos demais. Esa preservación era concibida non como unha defensa numantina fronte a hipotéticos invasores externos senón como unha obriga cívica con toda a humanidade. A aceptación e defensa da diversidade (dende a lingua ao patrimonio natural), non como un problema, senón como un valor que a humanidade no seu conxunto debe preservar, forman parte desa concepción progresista de Plácido Castro.

Plácido, por outra banda, concibía o nacionalismo, en primeiro lugar, como un movemento político que achega modernidade. Segundo, como a doutrina que mellor pode liberar a creatividade dos galegos. Terceiro, como un novo estilo de política, facendo da honestidade o principal valor cidadán. Cuarto, como unha nova forma de unión e nunca de separación, base esencial dun futuro estable, apostando polas nacións pequenas porque nelas se poden fortalecer mellor os ideais de democracia e de paz, sen ceder a tentacións militaristas nin imperialistas. Quinto, as relacións entre as diferentes comunidades nun estado plurinacional deben asentarse no recoñecemento do autogoberno e os poderes centrais deben promover a lealdade exaltando - e non negando e reprimindo- as identidades nacionais dos pobos que conforman unha determinada realidade estatal.

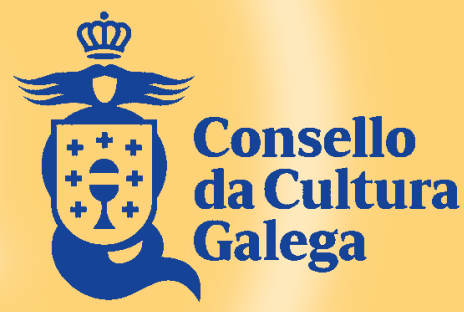

